\title{
Sosyal Politika Kapsamında Türkiye'de Yaşlanmaya İlişkin Ulusal Düzeydeki Düzenlemeler
}

\section{Arzu YILDIRIM ${ }^{1}$}

$\ddot{O} z$

Yașlanma, yașam boyu gelișim sürecinin en son aşamasını oluşturmaktadır. Gerek teknolojik gelișmeler, gerek sağlık teknolojisinde yaşanan gelişimle birlikte yaşlı nüfusta daha önceki çağlara göre bir artış yaşanmaktadır. Yaşlı nüfusunun artması, ülkelerin yaşlılara yönelik politika uygulamalarında daha fazla sorumluluk yüklemektedir. Yaşlıların fiziksel özelliklerinde yaşanan değişimler, hastalıkların artmasına dolayısıyla daha fazla bakıma ihtiyaç duymasına neden olmaktadır. Bir yandan teknolojinin gelişmesi diğer yandan toplum yapısının değişmesi sonucu geleneksel aile yapısı terk edilmeye başlanmıştır. Yaşlı bireylere ailelerin bakım ve gözetimi günümüzde kimi zaman mümkün olmamaktadır. Hayat koşullarının zorluğu ve yaşam şartlarının değişmesi yaşlıların bakımı konusunda başka alternatifler geliştirilmesini zorunlu kılmıştır. Bu noktada yaşlıların bakım hizmetlerini üstlenen huzur evleri, bakım evleri, yaşam merkezleri oluşturulma yoluna gidilmiştir. Türkiye'de de yaşlı nüfus oranında bir artış söz konusudur. Sanayileşme, toplumsal yapının değişmesi, teknolojinin hızlı bir şekilde gelişmesi ve yayılması yaşlı bireylerin sorunlarını artırmıştır. Türkiye'de yaşlı bireylerin hayatlarını sağlıklı, mutlu ve huzurlu bir şekilde devam ettirebilmeleri için, uzun vadeli politikaların hayata geçirilmesi gerekmektedir. Bu yüzden yaşlılara yönelik uygulanan sosyal hizmetler konusu önem taşımaktadır. Bu kapsamda çalışmanın amacı, yaşlılara yönelik uygulanan düzenlemelerden yola çıkarak, yaşlıların yaşamış oldukları sorunları ortaya koymak ve bu konuda öneriler getirmektir. Bu amaçla çalışmada, yaşlılara yönelik uygulanan sosyal hizmet uygulamaları kapsamlı bir şekilde ele alınmıştır. Ayrıca dünyada bazı ülkelerde yaşlılara yönelik uygulanan sosyal politika uygulamalarına da yer verilmiştir. Son olarak Türkiye'de yaşlilara yönelik düzenlenebilecek uygulamalar konusunda öneriler getirilmiştir.

Anabtar Kelimeler: Sosyal Hizmet, Yaşlılık, Sosyal Politika, Yaşlı Bakımı, Huzurevi

\section{Regulations on Aging at the National Level in Turkey in the Context of Social Policy}

\begin{abstract}
Aging constitutes the last stage of the lifelong development process. Along with the technological developments and the developments in health technology, the elderly population has increased compared to the previous ages. The increase in the elderly population imposes more responsibilities in the policy implementation of the countries towards the elderly. The changes in the physical characteristics of the elderly cause the diseases to increase and therefore needs more care. As a result of the development of technology on the one hand, and the change of the social structure, the traditional family structure has begun to be abandoned. Care and supervision of families for older individuals isn't possible today. Difficulty in living conditions and changing living conditions made it necessary to develop other alternatives for the care of the elderly. At this point, nursing homes, and living centers, which undertake care services for the elderly, have been established. Turkey is also concerned an increase in the elderly population. Industrialization, change of social structure, rapid development and spread of technology has increased the problems of elderly individuals. The lives of the elderly in Turkey, healthy, and happy to be able to continue in a peaceful manner, long-term policies must be implemented. The subject of social services applied to the elderly is important. In this context, the aim of the study is to reveal the problems experienced by the elderly and to make suggestions on this issue based on the regulations applied for the elderly. In this study, social work practices for the elderly are comprehensively discussed. In addition, in some countries in the world, social policy practices for elderly people are included. Finally suggestions are made about applications that can be arranged for the elderly in Turkey.
\end{abstract}

Key Words: Social Work, Elderly, Social Policy, Elderly Care, Nursing Home

\section{Atıf İçin / Please Cite As:}

Yıldırım, A. (2021). Sosyal Politika Kapsamında Türkiye’de Yaşlanmaya İlişkin Ulusal Düzeydeki Düzenlemeler. Manas Sosyal Arasttrmalar Dergisi, 10(3), 1889-1909.

Geliş Tarihi / Received Date: 07.10.2020

Kabul Tarihi / Accepted Date: 19.04.2021

\footnotetext{
${ }^{1}$ Dr. Öğr. Üyesi - Şırnak Üniversitesi Sağlık Bilimleri Fakültesi, a_ucar_44@hotmail.com

(iD ORCID: 0000-0002-8543-278X
} 


\section{Giriş}

Yaşlanma, fizyolojik olarak bazı özellikleri yavaş yavaş kaybetme sürecidir. Yaşlı bireylerin, yaşadıkları ekonomik, fiziksel, sosyal ve kültürel sorunlar, içinde bulundukları toplumun özelliklerine göre farkll1kklar göstermektedir. Yaşanan bu sorunlar kişiden kişise farkll1ık gösterse de genel olarak birbirleriyle ilişkili olmaktadır. Bu da yaşılıarı anlamak ve yaşlıların sorunlarına çözümler üretilmesi için bütün disiplinlerin birlikte çalışmasını zorunlu kılmaktadır.

Yaşlanma, kişinin hem fiziksel hem de ruhsal yönden değişime uğraması anlamına gelir. Bu durum toplumun yaşlılığa verdiği değer ile yakından ilişki içerisindedir. Çünkü yaşlılık sadece biyolojik bir durum değil aynı zamanda sosyal ve kültürel bir durumdur. Yaşam süresinin uzun olması, biyolojik ve zihinsel açıdan sağlıklı olmak, bilişsel ve sosyal yönden yeterli olmak, üretken olmak, yaşamdan zevk alabilmek gibi faktörler sağlıklı yaşlanmanın önemli göstergeleri arasındadır (Özürlü ve Yaşlı Hizmetleri Genel Müdürlüğü, 2013, s. 2).

Yaşlı nüfusun giderek artması, yaşlanan nüfusun bağımlılık oranlarını da artırmıştır. Özellikle sanayileşme sürecinin de etkisiyle geleneksel aile yapısı terk edilip çekirdek aileye doğru bir dönüşüm yaşanmıştır. Yaşanan bu değişim yaşlı bireyleri yalnız yaşamaya, kendi ihtiyaçlarını kendilerinin gidermesi durumuyla baş başa bırakmışıtır. Daha önce kırsal kesimde daha az bakım ve gözetim sıkıntısı yaşayan yaşlıların artık kentsel ya da kırsal mekân ayrımı fark etmeksizin birçok yaşlının bakım sıkıntısı yaşadığı görülmektedir. Yaşlıların sorunlarının bu şekilde artması yaşllık sorunlarına daha geniş bir yelpazeden bakılması gereğini ortaya çıkarmıştır. Yaşlıların bakımı ve ihtiyaçlarının karşılanması konusunda bütün kurum ya da kuruluşların toplumun tamamının katılımını sağlayacak bir mekanizma oluşturularak, etkili çözümler getirilmelidir.

Yaşlanma konusunda edinilen bilgiler sadece bizi süreç hakkında bilgi sahibi olmamızı sağlamaz, aynı zamanda yaşlanma konusunda hem kendimizin hem de diğer insanların daha duyarlı olması sağlanabilir. Yaşlıların sorunlarına daha etkili çözümler getirme aynı zamanda sosyal sorumluluk bilincinin oluşmasına yardımcı olur. Bütün insanlar yaşam boyu gelişim sürecinin bütün evrelerini yaşayacaktır. Bunlardan bir tanesi de yaşılıktır. Bugünün gençleri geleceğin yaşlılarını oluşturacaktır. Bugün yaşlıların yaşadıkları bütün sorunları ilerde bugünün gençlerinin yaşaması muhtemeldir (Altan ve Şişman, 2003, s. 4).

Türkiye'de yaşlı nüfus hızlı bir şekilde artma eğilimi göstermektedir. Yaşlıların bu süreci daha sağlıklı ve daha az sorunsuz bir şekilde geçirebilmeleri için bu konuda sosyal politikaların geliştirilmesi konusuna önem verilmesi gerekir. Bu araştırmanın amacı, Türkiye'de ve dünyada yaşıllara yönelik uygulanan sosyal politikaları ele almaktır. Sosyal devlet olmanın bir gereği olarak dezavantajlı gruplardan birini temsil eden yaşlılara yönelik uygulanan hizmetleri incelemek ve değerlendirmek temel amaçtır. Yaşlıların daha kaliteli bir hayat sürdürmelerini sağlamak için öneriler geliştirilmiştir.

Modernleşme ve kentleşmenin getirdiği etkilerle birlikte yaşlilar yalnız yaşamaya mahkûm edilmektedir. Çekirdek ailenin kabul görmesiyle yaşlıların bakımı konusu aile için sorun teşkil etmeye başlamış ve huzurevlerinde yaşamalarına yol açmıştır. Modern dünya düzeni ile birlikte yaşılıarın düşüncelerine önem verilmemeye başlanmış, kimi zaman emekli maaşları olan ya da yaşlılara verilen bakım aylıklarından yararlanmak için mecburiyetten bakılan bireyler olarak görülmüş kimi zaman da aile içinde huzursuzlukların nedeni olarak görülmüştür. Modern dünyanın getirdikleri yaşlılık olgusunun üzerinde önemle durulması gerektiğini ve bu yöndeki sosyal politikaların kapsamının genişletilmesi sonucunu ortaya çıkarmaktadır.

Yaşlılığı güvence altına alınmış mutlu ve doymuş insanların oluşturmuş oldukları toplumlarda yaşamın daha rahat devam ettirileceği kabul gören bir gerçektir. Zaman geçtikçe Türkiye'de yaşayan yaşlların sayısının artması nedeniyle kadın-erkek, genç-orta yaşı bütün insanların gelecekte aynı konumda olacakları bilinciyle, yaşılıarın yaşam kalitelerinin artırılması için yapılması gerekenlerin önceden tespit edilerek gerçekleştirilmesi önem taşımaktadır (Tuncel ve Uzun, 2019, s. 314).

\section{Yaşlılık Kavramı}

Yaş kavramı genel olarak biyolojik ve kronolojik yaş olmak üzere iki sınıflandırmaya gidilmektedir. Kronolojik olarak bütün insanlar aynı özellikleri taşımakla birlikte; biyolojik yaş bireyden bireye farklılık göstermektedir. Kronolojik yaş, insanın doğum tarihinden başlayıp daha sonraki süreçleri de kapsamaktadır. Kronolojik yaş nesnel ve somut olarak göstergelere dayanmaktadır (Altan ve Şişman, 2003, s. 5). 
Yaşlıllk zamana bağlı olarak kişilerin çevreye uyum sağlama yeteneği ile organizmanın diğer etkenler arasında uyum sağlama yeteneğinin azalmasına bağlı olarak ölüm riskinin yükselmesidir. Diğer bir tanımla yaşlılık fizyolojik bir olgu olmakla birlikte kişilerin sahip oldukları özelliklerin yavaş yavaş azalması durumudur. Yaşlanma, canlıların doğumdan başlayarak hayatının sona ermesine kadar sürekli olarak işleyen bir durumdur. Yaşlanma ile birlikte ağrıların artması, zihni olarak eskiye göre durağanlık gibi değişimler yaşanmaktadır. Kimi zaman topluma uyum sağlayamama, yalnızlık duygusu, vücudun fonksiyonlarında değişimler yaşanmaktadır (Ökten, 2015, s. 4-5).

Yaşlıllk, genel olarak yetişkinlik döneminden sonra gelen hem fiziksel olarak hem de ruhsal olarak bazı değişimlerin yaşandığı, psikolojik, sosyal ve fiziksel olarak değişimlerin yaşandığı bir dönem olarak ifade edilebilir (Narin, 2019, s. 11).

Yaşlılık kavramı genel olarak kişilere özgü bir durum olmakla beraber, toplumun değer yargiları ve diğer faktörler yaşlıya olan bakış açısını ortaya koymaktadır. Bu bakımdan toplumun yaşlıya bakışı ülkeden ülkeye toplumdan topluma değişim göstermektedir. Bu yüzden yaşlillk sadece biyolojik bir olgu olmayıp sosyo-kültürel bir olgudur (Çohaz, 2010, s. 122).

Özellikle gelişmiş ülkelerde, tıbbın ve teknolojinin gelişmesiyle birlikte, yaşlı nüfusun toplam nüfusa oranı gittikçe artmaktadır. Dolayısıyla yaşlılık kavramı, içinde bulunduğu toplum yapısına, zamana, kişilerin eğitim düzeyine, kişilerin ekonomik durumlarına, cinsiyetlerine, fiziksel ve psikolojik durumlarına göre değişim göstermektedir. Kesin olarak bir yaşlılık sınırı belirlemek mümkün değildir. Yaşlılık kişilerin çalışma kabiliyetini kısmen ya da tamamen kaybetmesi durumudur (Cengiz, 2018, s. 37).

Birçok ülke, kurum ya da kuruluş tarafindan ortaya konulan yaş kategorilerinin nesnel bir karşıllı̆̆1 bulunmamaktadır. Başka bir ifade ile kimin çocuk, kimin genç, kimin yetişkin ya da yaşlı sayılacağının bütün zamanlar ve bütün toplumlar için genel geçer bir tanımının olması mümkün değildir. Çünkü belirtilen yaş kategorileri birer toplumsal kurgu olarak karşımıza çıkmaktadır. Örneğin "çocukluk kategorisi hangi yaş aralığını kapsar?" sorusunun bütün toplum ve bütün zaman için geçerli kabul edilecek tek bir cevabi bulunmamaktadır. Sanayi öncesi dönemlerde tarımla uğraşan toplumlarında insanlar çok erken yaşta üretim hayatına katıldığı ve çok erken yaşta evlendiği için gençlik o dönemlerde çok kısa süren bir dönem olarak görülmekte idi. Bugün ise Türkiye'de kırsal bölgelerde yaşayan toplumlarda çocukluk dönemi yaş aralı̆̆ ile orta veya üst sınıf kentli bir toplumdaki çocukluk anlayışı birbirinin aynısı değildir. Hatta günümüzde tüketim toplumunda yaş grupları daha da çoğalılış durumdadır. Bu yaş aralıklarını belirlemek belki sosyal politikaları belirlemek amacıyla kullanılması dolayısıyla önemli olabilir, ancak yaşlılık kategorisi de diğer yaş kategorilerinde olduğu gibi öznel bir durumdur; kimin yaşlı sayılacağ1 konusu kültürden kültüre farklllık göstermektedir.(Çayır, 2012, s. 2-3).

Toplumu oluşturan bireylerin yaşlara göre dağılımları ifade edildiğinde yaşların gösterilmesi yaş piramidini meydana getirmektedir. Eğer piramidin alt kısmı geniş, yukarıya çıktıkça gittikçe azalıyorsa bu piramid ülkede normal bir seyir izlendiğini göstermektedir. Bizim ülkemizde de durum böyledir. Diğer genç nüfuslu ülkelerde de durum aynıdır. Ancak yaşlı nüfusu fazla olan ülkelerde piramidin ortası geniştir ve yukarıya çıktıkça gittikçe azalan bir eğilim göstermektedir (Narin, 2019, s. 16).

Nüfusun yaşlanmasında temel demografik göstergeler; doğurganlık oranı, ölüm oranı ve net göç düzeyidir. Önceki yıllarda ABD ve AB'ye üye ülkelerde doğurganlık oranları keskin bir şekilde düşmüştür (Vepachedu, 2019, s. 1).

"Yaşl1lık" olarak adlandırılan dönem bütün insanların kaçması mümkün görünmeyen bir süreci ifade etmektedir. Yaşlılık dönemi ile beraber yaşlılığın getirdiği kendine özgü özellikleri ile karşılaşılmaması mümkün görünmemektedir. Bu bakımdan yaşlılık döneminde fiziki olarak yaşanan güçsüzlük ve diğer durumlarda yaşanan zayıflıkların ve eksikliklerin varlığı kaçınılmazdır. Yaşlılar bu özelliklerini kaybetmelerinden dolayı hayatlarını devam ettirecekleri temel ve basit ihtiyaçlarını giderme konusunda sıkıntı yaşayabilmektedir. Bu noktada yaşlıların desteklenmesi konusu önemli olmaktadır (Taşcı, 2010, s. 176).

Yaşlılık, sadece insanların aktivitelerinin azalmaya başladığı biyolojik bir süreç olarak görülmemelidir. Yaşlılık, hem bazı fiziksel yeterliliklerin azalması hem de çalışma yaşamından uzaklaşma gibi nedenlerle insanların psikolojik sorunlar yaşaması muhtemel olan bir dönemdir. Esasen yaşlılar bu nedenlerden dolayı dezavantajlı grup olarak algılanmaktadır. Dolayısıyla yaşlılar ülkelerin sosyal politika alanlarının da özel ilgi alanını oluşturmaktadır. Yaşı nüfusun toplumun bütün bireyleriyle entegre bir şekilde yaşayabilmesi en 
basit şekli ile sosyal içermenin sağlanmasına katkı sağlayacaktır. Bu nedenle öncelikle yaşlı nüfusu toplumsal değerlerden biri olarak kabul görüp kapsayıcı nitelikte sosyal politikaların geliştirilmesi zorunlu görülmektedir (Çolak ve Özer, 2015, s.116).

Yaşlılık kavramı ile ilgili yapılan bütün tanımlar dikkate alındığında yaşlılık ile ilgili iki temel olguya ulaşıldığı görülmektedir. Birincisi yaşlılıkla birlikte yitirilmeye başlanan duyu ve yetilerdeki kayıplar ile yaşlılı̆̆n olumsuz fonksiyonlarına dikkat çekilirken, ikincisi yaşlanma ile birlikte edinilen tecrübe, bilgi birikimi, olaylara karşı daha 1lımlı ve tutarlı bir bakış açısı gibi yaşlılı̆̆ın olumlu yönlerine dikkat çekilmektedir (Çağlar, 2014, s. 149).

\section{Türkiye'de Yaşlı Nüfus}

Türkiye'de yaşlı nüfusun demografik olarak eğilimleri dikkate alınırsa, Aralık 2019 itibari ile toplam nüfusu 83 milyon 154 bin 997 kişiye ulaşmıştır. Buna göre bir önceki yıla göre 1 milyon 151 bin 115 kişi artış olmuştur. Nüfus piramidindeki yapısal değişim geçen yıla göre aynı şekilde devam etmiştir. Doğurganlık ve ölümlülük hızlarındaki azalmaya bağlı olarak yaşlı nüfusun arttığ1 görülmektedir.

Tablo 1. Seçilmiş Ülkelere Göre Yaşl Nüfus Oramı, (2019)

\begin{tabular}{cllc}
\hline Ülke & Toplam Nüfus & Yaşh Nüfus & Yaşlı Nüfus Orant \\
\hline Dünya & $7,604,656,633$ & $703,711,487$ & 9,3 \\
ABD & $330,268,840$ & 944,669 & 2,6 \\
Almanya & $80,313,272$ & $18,204,472$ & 22,7 \\
İsveç & $10,121,794$ & $2,072,218$ & 20,5 \\
İtalya & $62,334,799$ & $13,633,754$ & 21,9 \\
Monako & 30,825 & 10,517 & 34,1 \\
Japonya & $125,853,035$ & $36,240,891$ & 28,8 \\
İngiltere & $65,436,510$ & $11,998,565$ & 18,3 \\
Türkiye & $83,154,997$ & $7,550,727$ & 9,1 \\
\hline
\end{tabular}

Kaynak: TUİK, İstatistiklerle Yaşlilar, 2019

Yukarıdaki seçilmiş ülkelere göre yaşlı nüfus oranlarına dikkat edildiğinde 2019 yılında dünya nüfusunun yaklaşık \%9,3'ünü yaşlı nüfus oluşturmuştur. Bu tabloya göre en yüksek yaşlı nüfus oranına sahip ülke \%34,1 ile Monako birinci siradadır. Bunu sirası ile \%28,8 ile Japonya ve \%22,7 ile Almanya takip etmektedir. Bu siralamaya göre Türkiye 167 ülke arasında 66. sırada olduğu görülmektedir (http://www.tuik.gov.tr/, Erişim Tarihi:16.05.2020).

Tablo 2. Cinsiyete Göre Yaşlı Nüfus ve Yaşlı Nüfusun Toplam Nüfus İ̧indeki Oram, (2010-2080)

\begin{tabular}{llll}
\hline Yll & Toplam & Erkek & Kadin \\
\hline 2010 & $5,327,736$ & $2,331,029$ & $2,996,707$ \\
2011 & $5,490,715$ & $2,397,925$ & $3,092,790$ \\
2012 & $5,682,003$ & $2,473,913$ & $3,208,090$ \\
2013 & $5,891,694$ & $2,561,074$ & $3,330,620$ \\
2014 & $6,192,962$ & $2,699,423$ & $3,493,539$ \\
2015 & $6,495,239$ & $2,843,442$ & $3,651,797$ \\
2016 & $6,651,503$ & $2,919,392$ & $3,732,111$ \\
2017 & $6,895,385$ & $3,033,433$ & $3,861,952$ \\
2018 & $7,186,204$ & $3,170,132$ & $4,016,072$ \\
2019 & $7,550,727$ & $3,337,260$ & $4,213,467$ \\
2023 & $8,867,951$ & $3,964,105$ & $4,903,845$ \\
2030 & $12,066,092$ & $5,459,819$ & $6,606,272$ \\
2040 & $16,373,971$ & $7,451,781$ & $8,922,190$ \\
2060 & $24,242,787$ & $11,024,497$ & $13,218,290$ \\
2080 & $27,413,359$ & $12,556,365$ & $14,856,994$ \\
\hline
\end{tabular}

Kaynak: TUİK, İstatistiklerle Yaşlılar, 2019

Tablo 2'de 2010 ve 2019 y1lları arasında cinsiyete göre yaşlı nüfus ve yaşlı nüfusun toplam nüfus içindeki oranı verilmektedir. Ayrıca 2023, 2030, 2040, 2060 ve 2080 y1llarında tahmin edilen yaşlı nüfusu ve toplam nüfusa oranı verilmektedir. Verilen tabloya göre toplam nüfus içindeki yaşlı nüfus oranı yaklaşık olarak 2,3 oranında artış göstermiştir. 2080 yılında toplam yaşlı nüfusun 27413359 ile en yüksek sayıya ulaşacağ1 görülmektedir. 
Ülkemizde yaşlı nüfusun yaşadığı yerleşim yerine göre dağılımları incelendiğinde; yaşlı nüfusun \%86,6's1 (6.537.647 kişi) şehirde yaşamaktayken, \%13,4'ünün (1.013.080 kişi) köylerde yaşadığ1 görülmektedir (TUİK, İstatistiklerle Yaşlilar, 2019).

Tablo 3. Yass Grubu ve Cinsiyete Göre Yaşli Nüfus, (2019)

\begin{tabular}{lllll}
\hline Yaş Grubu & Toplam & Erkek & Kadın & Toplam Yaşl Nüfus İcindeki Oranı \\
\hline $65-69$ & $2,722,672$ & $1,301,371$ & $1,421,301$ & 36,1 \\
$70-74$ & $2,016,913$ & 907,850 & $1,109,063$ & 26,7 \\
$75-79$ & $1,308,299$ & 560,695 & 747,604 & 17,3 \\
$80-84$ & 817,730 & 323,732 & 493,998 & 10,8 \\
$85-89$ & 497,410 & 192,938 & 304,472 & 6,6 \\
$90+$ & 187,703 & 50,674 & 137,029 & 2,5 \\
Toplam & $7,550,727$ & $3,337,260$ & $4,213,467$ & 100 \\
\hline
\end{tabular}

Kaynak: TUİK

Tablo 3’te 2019 yılında yaşlı nüfusun yaş grubu ve cinsiyete göre dağılımı yer almaktadır. Tabloya göre toplam yaşlı nüfusun 36,1 oranında 65-69 yaş arasında olduğu görülmektedir. 2019 yılında 65-69 yaşlı nüfusu 2722672 kişiye ulaşmıştır.

Ülkemizde nüfus piramidinin yapısının fazla değişmemesinin nedeni; doğum oranındaki azalma ve ölümlülük oranının azalmasıyla yaşlı nüfusu artış göstermektedir. Sağlıkta teknolojide yaşanan hızlı ilerlemeler ve iyileşmeler sayesinde yaşlı nüfusu toplam nüfus içinde giderek artış göstermektedir.

2015-2018 yılları arasındaki yaşlı nüfusun eğitim durumlanı ve cinsiyetlere göre dağllımlarına göre, eğitim durumlarına göre yaşlı nüfus incelendiğinde 2015 yllında yaşlı nüfusun $\% 43,0$ ilkokul mezunu, \% 5,2 ile ortaokul veya dengi okul mezunu, $\% 5,6$ ile lise veya dengi okul mezunu, $\% 5,4$ ile yükseköğretim mezunu olduğu görülmektedir. 2018 yllında ise, yaşlı nüfusun \%45,0 ilkokul mezunu, \%6,5 ile ortaokul veya dengi okul mezunu, \%6,8 ile lise veya dengi okul mezunu, \%6,6 ile yükseköğretim mezunu olduğu görülmektedir. Yaşlı nüfusun eğitim durumları yıllara göre bakıldığında sürekli olarak eğitim durumlarında artış olduğu görülmektedir. Yaşlı nüfusun cinsiyete göre dağılımı dikkate alındığında eğitim seviyesinin her yllda yaşlı erkek nüfusunun yaşlı kadın nüfusundan fazla olduğu görülmektedir (TÜİK, İstatistiklerle Yaşlilar, 2019).

Yaşlı nüfusun cinsiyete göre yoksulluk oranına bakılacak olunursa; 2014 yllında yaşlı nüfusun $(65+)$ yoksulluk oranı \%18,3 iken 2018 y1lında yaşlı nüfusun yoksulluk oranı \%16,4'e düşmüştür. Yoksul yaşlı erkek nüfusun oranı 2014 yllında \%18,3 iken, 2018 yllında \%14,4'e düşmüştür. Yoksul yaşlı kadın nüfusun oranı 2014 yılında \%18,2 iken, 2018 yılında 17,9'a düşmüştür. Yaşlı nüfusun yoksulluk oranı cinsiyet bazlı olarak değerlendirildiğinde erkek yaşlı nüfusun yoksulluk oranı yıllara göre düşüş göstermektedir. 2018 yllında bir önceki yıla göre yükselme görülmüştür. Kadın yaşlı nüfusun yoksulluk oranı 2015 yllında bir önceki yıla göre artış gösterirken 2016 ve 2017 ylllarında düşüş olmuştur; ancak 2018 yllında tekrar yükselişe geçmiştir (TÜíK, İstatistiklerle Yaşlilar, 2019).

\section{Aktif Yaşlanma Endeksi}

Aktif yaşlanma endeksi, bireylerin aktif yaşlanmalarını sağlaması açısından önemli olmaktadır. Bireylerin kendi potansiyellerinin farkında olup güçlü bir kişilik geliştirmelerine olanak sağlayacaktır. Aktif yaşlanma endeksi, yaşlı bireylerin yaşamlarının büyük bir bölümünü kapsamaktadır. Ülkelerin politika uygulayıcılarına önemli oranda yardımcı olmaktadır. Diğer ülkelerde bulunan yaşlıların potansiyellerinin karşılaştırılmasına imkân tanımaktadır. Bu endeks yaşlıların sosyal hayata aktif bir şekilde katılımını sağlamayı esas almaktadır.

Aktif yaşlanma endeksi, 2012 yılında Avrupa Nesiller Arası Aktif Yaşlanma ve Nesiller Arası Dayanışma Yılı kapsamında istihdam, topluma katılım, bağımsız sağlıklı ve güvenli yaşam, aktif yaşlanma için kapasite ve destekleyici çevre olmak üzere 4 ana başlık ve 22 göstergeden oluşmaktadır. Türkiye bu proje kapsamında pilot çalışma yapmıştır. Bu pilot çalışmanın raporları aşağıda yer almaktadır. 
Tablo 4. İstibdam

\begin{tabular}{|c|c|c|c|c|}
\hline Gösterge & Y11 & 2008 & 2010 & 2012 \\
\hline \multirow{3}{*}{ İstihdam oranı yaş grubu (55-59) } & Kadin & 16,3 & 18,8 & 19,6 \\
\hline & Erkek & 44,7 & 46,3 & 50,8 \\
\hline & Toplam & 30,3 & 32,4 & 35,0 \\
\hline \multirow{3}{*}{ İstihdam oranı yaş grubu (60-64) } & Kadın & 13,1 & 14,8 & 15,9 \\
\hline & Erkek & 35,8 & 37,7 & 40,4 \\
\hline & Toplam & 23,8 & 25,8 & 27,7 \\
\hline \multirow{3}{*}{ İstihdam oranı yaş grubu (65-69) } & Kadin & 9,2 & 10,6 & 11,3 \\
\hline & Erkek & 27,7 & 29,0 & 29,4 \\
\hline & Toplam & 17,5 & 18,9 & 19,6 \\
\hline \multirow{3}{*}{ İstihdam oranı yaş grubu (70-74) } & Kadin & 5,9 & 6,3 & 6,8 \\
\hline & Erkek & 19,4 & 20,7 & 21,0 \\
\hline & Toplam & 11,9 & 12,7 & 13,1 \\
\hline
\end{tabular}

Kaynak: TÜİK, İstatistiklerle Yaşlılar, 2019

Tablo 4'te yaş gruplarının yıllara göre istihdam raporu yer almaktadır. Buna göre 2008 yılında 55-59 yaş grubunun istihdam oranı 30,3 iken 2012 yllında 35,0'a ulaşmıştır. Aynı şekilde diğer yıllara ve istihdam oranı yaş gruplarına bakıldığında istihdam oranları sürekli artış eğilimi göstermiştir.

Tablo 5. Topluma Katılim

\begin{tabular}{llcc}
\hline Gösterge & Y11 & 2007 & 2011/12 \\
\hline \multirow{3}{*}{ Gönüllü faaliyetler } & Kadın & 1,6 & 0,0 \\
& Erkek & 3,7 & 1,0 \\
& Toplam & $\mathbf{2 , 7}$ & $\mathbf{0 , 5}$ \\
\hline \multirow{3}{*}{ Çocuklara ve torunlara bakma } & Kadın & 16,9 & 33,4 \\
& Erkek & 4,8 & 27,6 \\
& Toplam & $\mathbf{1 0 , 7}$ & $\mathbf{3 0 , 6}$ \\
\hline \multirow{3}{*}{ Kaha yaşlı yetişkinlere bakma } & Erkek & 7,1 & 17,8 \\
& Toplam & 8,4 & 10,9 \\
\hline \multirow{2}{*}{ Siyasi hayata katıllım } & Kadın & $\mathbf{7 , 8}$ & $\mathbf{1 4 , 3}$ \\
\hline & Erkek & 2,7 & 1,5 \\
& Toplam & 7,3 & 6,4 \\
\hline
\end{tabular}

Kaynak: TÜİK, İstatistiklerle Yaşlılar, 2019

Tablo 5'te yıllara göre topluma katılım oranları yıllara ve cinsiyete göre yer almaktadır. Gönüllü faaliyetler, çocuklara ve torunlara bakma, daha yaşlı yetişkinlere bakma ve siyasi hayata katılım şeklinde dört göstergelere ayrılmıştır. Gönüllü faaliyetler ve siyasi hayata katılım göstergesine bakıldığında 2007 yılından 2011 ve 2012 yllına gelindiğinde bir düşüş görülmektedir. Çocuklara ve torunlara bakma ve daha yaşlı yetişkinlere bakma göstergesi 2007 yllından 2011 ve 2012 yllına gelindiğinde artış görülmektedir.

Bağımsız, sağlıklı ve güvenli yaşan endeksi yıllara ve cinsiyete göre yer alan veriler incelendiğinde; fiziksel egzersiz, sağlık hizmetlerine erişim, bağımsız yaşama, göreli medyan gelir, yoksulluk riski, ciddi maddi yoksunluk, fiziksel güvenlik, hayat boyu öğrenme şeklinde göstergelere ayrılmıştır. Bağımsız yaşama göstergesinde 2008 yllına ait veriler bulunmamaktadır. 2010 yllında 57,6 iken 2012 yllında 59,9'a ulaşmıştır. Yoksulluk riski ise 2008 yllında 89,1 iken, 2012 yllında 85,6'ya düşmüştür (TÜiK, İstatistiklerle Yaşllar, 2019).

Aktif yaşlanma için kapasite ve destekleyici çevre endeksi yıllara ve cinsiyet dağılımı incelendiğinde; 55 yaşında iken kalan beklenen yaşam süresi, 55 yaşında iken beklenen sağlıklı yaşam süresi, akıl sağllğı, btk kullanımı, sosyal bağlanmışlık, eğitim düzeyi şeklinde göstergelere ayrılmaktadır. 55 yaşında iken beklenen yaşam süresi 2009 yllında 50,0 iken 2012 yllında 52,0’a yükselmiştir. Eğitim düzeyi 2008 yllında 12,0 iken 2012 yıllnda 14,0’a yükselmiştir (TÜIK, İstatistiklerle Yaşlılar, 2019).

\section{Türkiye'de Yaşlılara Yönelik Uygulanan Yasal Düzenlemeler}

Türkiye'de yaşlılara yönelik uygulanan yasal düzenlemelerin başında hiç kuşkusuz 1982 Anayasası gelmektedir. Anayasanın 2. maddesinde "Türkiye Cumhuriyeti, toplumun huzuru, millî dayanışma ve adalet anlayışı içinde, insan haklarına saygılı, Atatürk milliyetçiliğine bağlı, başlangıçta belirtilen temel 
ilkelere dayanan, demokratik, lâik ve sosyal bir hukuk devletidir" ifadesi yer almaktadır. Buna göre ülkemiz bir sosyal hukuk devleti olarak kabul edilmiştir ve sosyal hukuk devletinin gereği olarak yaşlilara yönelik sosyal hizmet uygulamalarının yapılması gerektiği dolaylı olarak belirtilmiştir.

Anayasa'nın 5. maddesinde "Devletin temel amaç ve görevleri, Türk milletinin bağımsızlığını ve bütünlügünü, ülkenin bölünmezliğini, Cumhuriyeti ve demokrasiyi korumak, kişilerin ve toplumun refah, huzur ve mutluluğunu sağlamak; kişinin temel hak ve hürriyetlerini, sosyal hukuk devleti ve adalet ilkeleriyle bağdaşmayacak surette sınırlayan siyasal, ekonomik ve sosyal engelleri kaldırmaya, insanın maddî ve manevî varlığının gelişmesi için gerekli şartları hazırlamaya çalşsmaktır” hükmü bulunmaktadır. Buna göre sosyal hukuk devleti vurgusu yine yapılmıştır. Sosyal devletin yerine getirmekle sorumlu olduğu görevleri yerine getirmeye engel olabilecek her türlü maddi ya da manevi engelleri kaldırmak zorunda olduğunu belirtmiştir. Dolaylı olarak yaşılıarın hayatlarını devam ettirebilmelerini sağlamak ve karşılaştıkları her türlü maddi ya da manevi engelleri azaltmakla sorumlu tutulmuştur.

Anayasa'nın 10. maddesinin 1. fikrasında; "Herkes, dil, ırk, renk, cinsiyet, siyasî düşünce, felsefî inanç, din, mezhep ve benzeri sebeplerle ayırım gözetilmeksizin kanun önünde eşittir." ifadesi ile herkesin kanun önünde eşit olduğu kabul edilmiştir. Hiç kimsenin bu sayılan nedenlerden dolayı farklı bir muameleye maruz kalması kabul edilmemektedir. Bu madde ile dolaylı olarak da olsa devletin hizmet verdiği bireylere sahip oldukları özelliklerden dolayı farklı bir hizmet sunmama sorumluluğu yüklemiştir. Ayrıca Anayasa'nın 10. maddesinin ek fikrasında "Çocuklar, yaşlılar, özürlüler, harp ve vazife şehitlerinin dul ve yetimleri ile malul ve gaziler için alınacak tedbirler eşitlik ilkesine aykırı sayılmaz." ifadesi yer almaktadır. Buna göre toplumda dezavantajlı grupta olan yaşlılar için olumlu ayrımcllğı̆n uygulanmasının eşitlik ilkesine aykırı olmayacağı belirtilmiştir.

Anayasanın 49. maddesinde; "Çalışma, herkesin hakkı ve ödevidir. Devlet, çalışanların hayat seviyesini yükseltmek, çalışma hayatını geliştirmek için çalışanları ve işsizleri korumak, çalışmayı desteklemek, işsizliği önlemeye elverişli ekonomik bir ortam yaratmak ve çalışma barışını sağlamak için gerekli tedbirleri alır." ifadesine göre çalışma hakkının herkesin hakkı olduğu kabul edilerek yaşlıların iş hayatında karşılaşabilecekleri her türlü engeli kaldırma ve herhangi bir ayrımcilığa maruz bırakılmamasını belirtmektedir.

Anayasanın 50. maddesinde ise "Kimse, yaşına, cinsiyetine ve gücüne uymayan işlerde çalıştırllamaz. Küçükler ve kadınlar ile bedenî ve ruhî yetersizliği olanlar çalısma şartları bakımından özel olarak korunurlar." ifadesi yer almaktadır. Buna göre bedensel ve ruhsal olarak yetersiz olan yaşlıların çalışma koşulları bakımından özel olarak korunması gerektiği belirtilmiştir. Yaşlıların güçlerinin üstünde herhangi bir işte çalıştırılmaması gerektiği belirtilmiştir.

Anayasa'nın 56. maddesinde; "Herkes, sağlıklı ve dengeli bir çevrede yaşama hakkına sahiptir. Çevreyi geliştirmek, çevre sağlığını korumak ve çevre kirlenmesini önlemek Devletin ve vatandaşların ödevidir. Devlet, herkesin hayatını, beden ve ruh sağllğı içinde sürdürmesini sağlamak; insan ve madde gücünde tasarruf ve verimi artırarak, işbirliğini gerçekleştirmek amacıyla sağlık kuruluşlarını tek elden planlayıp hizmet vermesini düzenler. Devlet, bu görevini kamu ve özel kesimlerdeki sağlık ve sosyal kurumlarından yararlanarak, onları denetleyerek yerine getirir. Sağlık hizmetlerinin yaygın bir şekilde yerine getirilmesi için kanunla genel sağlık sigortası kurulabilir." ifadesi yer almaktadır. Buna göre herkesin sağlıklı bir çevrede yaşamını sürdürmesi hakkı bulunmaktadır. Yaşılıar da devletin bir vatandaşı olduğu için yaşılıarın sağlıklı bir çevrede yaşamlarını devam ettirmek, bedensel ve ruhsal sağlıklarını devam ettirmek ve korumak ve kamu ya da özelde hizmet veren sağlık kuruluşlarından yararlanma haklarının olduğu ifade edilmektedir.

Anayasa'nın 60. maddesinde "Herkes, sosyal güvenlik hakkına sahiptir. Devlet, bu güvenliği sağlayacak gerekli tedbirleri alır ve teşkilatı kurar.” ifadesine göre ülkede yaşayan herkesin sosyal güvenlik hakkının olduğunu ve bunu devletin sağlaması gerektiği belirtilmiştir. Yaşlıların da sosyal güvenlik hakkının olduğu vurgulanmıştır.

Anayasanın 61. maddesinde; "Devlet, harp ve vazife şehitlerinin dul ve yetimleriyle, malûl ve gazileri korur ve toplumda kendilerine yaraşır bir hayat seviyesi sağlar. Devlet, sakatların korunmalarını ve toplum hayatına intibaklarını sağlayıcı tedbirleri alır. Yaşlılar, devletçe korunur. Yaşlılara Devlet yardımı ve sağlanacak diğer haklar ve kolayliklar kanunla düzenlenir. Devlet, korunmaya muhtaç çocukların topluma kazandırılması için her türlü tedbiri alır. Bu amaçlarla gerekli teşkilat ve tesisleri kurar veya kurdurur." ifadesine göre dezavantajlı grupta yer alan bütün vatandaşların devlet tarafindan korunması gerektiği belirtilmiştir. Yaşlılar bu maddede özel olarak ifade edilmiştir. Yaşlıların karşılaştıkları sorunları devletin 
çözüme kavuşturması, sağlanacak diğer haklardan yararlandırılması devletin görevleri arasında sayılmaktadır.

1983 yllında 2828 sayılı Sosyal Hizmetler ve Çocuk Esirgeme Kurumu Kanunu kabul edilmiştir. Ekonomik ve sosyal açıdan yoksun olan özellikle kadın, çocuk, engelli, yaşlı ve diğer özel ihtiyaç gruplarının ihtiyaçlarının karşılanmasını, sorunlarına çözüm getirilmesini, yaşam koşullarının iyileştirilmesine yönelik olarak yerel ve ulusal düzeyde hizmet vermeyi amaç edinmiştir. Daha sonra Sosyal Hizmetler ve Çocuk Esirgeme Kanunu 2011 yilında kabul edilen "633 Say1l Aile ve Sosyal Politikalar Bakanlı̆̆ının Teşkilat ve Görevleri Hakkında Kanun Hükmünde Kararname” ile Sosyal Hizmetler Kanunu olarak yeniden düzenlenmiştir. Yine aynı düzenleme ile "Sosyal Hizmetler ve Çocuk Esirgeme Kurumu" nun kapatılmasına karar verilmiştir. Bunun yerine Engelli ve Yaşlı Hizmetleri Genel Müdürlüğü kurulmuştur. 2018 y1lında 703 sayılı Kanun Hükmünde Kararname kabul edilmiştir. Böylece 633 sayllı Kanun Hükmünde Kararnamenin pek çok maddesi yürürlükten kaldırılmıştır. Aile ve Sosyal Politikalar Bakanlığı, Çalışma ve Sosyal Güvenlik Bakanlığı ile tek çatı altında toplanmaya karar verilmiştir. "Aile, Çalışma ve Sosyal Hizmetler Bakanlığı" olarak tek çatı altında toplanmıştır.

633 sayılı Kanun Hükmünde Kararnamede Aile ve Sosyal Politikalar Bakanlığı'nın görevleri; engelli ve yaşlı kişilerin hiçbir engel ve dışlanmaya maruz kalmadan sosyal hayata etkin bir şekilde katılmalarını sağlamak amacıyla ulusal düzeyde politikaların belirlenmesi ve yürütülmesini sağlamak, bu alanda hizmet veren bütün kamu kurum ve kuruluşları arasında işbirliğini sağlamak şeklinde ifade edilmiştir. Bu madde ile bakanlığa yaşlıların sosyal hayatta aktif bir şekilde katılımını sağlamak üzere gerekli politikaları almak ve uygulamakla sorumlu kılınmıştır. Bu uygulama ile yaşlıların sosyal yardım hizmetlerinin gördürülmesi görevi Aile ve Sosyal Politikalar Bakanlığı'nın sorumlulukları arasında sayılmıştır. Aynı zamanda Aile ve Sosyal Politikalar Bakanlığı'na sosyal yardımlar ve sosyal hizmetler konusunda kamu kurum ve kuruluşları arasındaki işbirliğini sağlamak üzere gerekli prosedürleri hazırlamak, ulusal ve uluslararası alanda sosyal yardımlar ve sosyal hizmetler ile alakalı gerekli gelişmeleri takip etmek, uygulanmasını sağlamak üzere önemli görevler yüklenmiştir.

2828 sayılı SHÇEK Kanunu'nu esas alınarak "Kamu Kurum ve Kuruluşları Bünyesinde Açılacak Huzurevlerinin Kuruluş ve İşleyiş Esasları Hakkındaki Yönetmelik" oluşturulmuştur. Bu yönetmeliğin oluşturulma amac1; huzurevleri açacak olan bütün kamu kurum ve kuruluşlarının huzurevleri açlma koşulları, huzurevlerinde çalışacak personelin taşıyacağı özellikler, çalışma koşulları gibi birçok konuda yasalara uygun bir şekilde hizmet vermelerini sağlamak amacıyla oluşturulmuştur. Bu yönetmelikte yaşli; ekonomik ve sosyal açıdan bakıma ve korunmaya muhtaç olan yaşlı kişiler olarak ifade edilmiştir.

2008 yılında "Yaşlı Hizmet Merkezlerinde Sunulacak Gündüzlü Bakım ile Evde Bakım Hizmetleri Hakkında Yönetmelik" adlı yönetmelik kabul edilmiştir. Bu yönetmeliğe göre yaşlılara yönelik olarak evde ve gündüzlü bakım hizmetleri sunulmaktadır. Bu yönetmelik huzurevlerinde kalmak istemeyen yaşılların bakım ihtiyaçlarını evde ve gündüzlü olmak koşulu ile gerçekleştirmek için gerekli prosedürleri belirlemek ve uygulanmasını sağlamak amacı ile oluşturulmuştur. Bu yönetmeliğe göre evde bakım hizmeti birimi; akıl ve ruh sağlığı konusunda hiçbir sorunu olmayan, tıbbi olarak bakım ihtiyacı gerektirmeyen, ailesinin tek başına bakması yeterli düzeyde olmayan yaşlıların evdeki hayatlarını kolaylaştırmak ve yardımcı olmak amacıyla yaşılıara yönelik sosyal ve psikolojik hizmetleri kapsamaktadır. Gündüzlü bakım hizmeti ise; evde ailesiyle birlikte yaşayan yaşlıların, yalnız yaşayan ya da demans, alzheimer gibi sağlık sorunları olan yaşlıların günlük faaliyetlerini aksamadan yapmalarına yardımcı olmak, yaşam koşullarını iyileştirmek, sosyal yönden gelişmelerini sağlamak amacıyla ilgilerine göre aktiviteler düzenleyerek katılımlarını sağlamak gibi yaşlıların yaşam koşullarının iyileştirilmesini sağlamak amacını taşımaktadır.

Devlet Planlama Teşkilatı Müsteşarlığı (DPT), Sosyal Hizmetler ve Çocuk Esirgeme Kurumu Genel Müdürlüğ̈̈ (SHÇEK) ve ilgili diğer sivil toplum kuruluşlarının katılımları ile 2. Dünya Yaşlılık Asamblesi sürecinde hazırlanan "Yaşlanma Uluslararası Eylem Planı", nüfusu gittikçe yaşlanma eğilimi gösteren ülkemiz açısından önemli sayılacak tedbirler içermektedir. Kararları tavsiye niteliğindedir. SHÇEK Genel Müdürlüğü ve DPT Müsteşarlığı tarafindan bu eylem planında uygulamaya konulması gereken konuların belirlenmesi, sektörler arasında faaliyet planlamalarının yapılması amacıyla adım atılmıştır. DPT Müsteşarllğ1 Sosyal Sektörler ve Koordinasyon Genel Müdürlüğünün koordinatörlüğü ve Sosyal Hizmetler ve Çocuk Esirgeme Kurumunun işbirliği ile bu kapsamda Birleşmiş Milletler Nüfus Fonu, çeşitli kamu kurum ve kuruluşları, üniversite ve sivil toplum kuruluşlarının temsilcilerinden oluşan "Ulusal Komite" tarafından 2004 yılında başlatılan çalışmaların 2005 yılında tamamlanarak "Türkiye'de Yaşlıların Durumu ve Yaşlanma Ulusal Eylem Planı”nı hazırlamıștır. Bu Eylem Planı, Yüksek Planı Kurulu'nun 2007 
tarihli kararı ile kabul edilmiştir. Bu raporda Türkiye'de yaşayan yaşlıların mevcut durumu incelenmiş ve yaşlanma ile ilgili gerçekleştirilecek faaliyetler belirlenmiştir. Eylemleri kapsayan bölümde, yaşlılar ve kalkınma, yaşlılıkta sağlık ve refahın artırılması ve yaşlılıkta olanaklar sunan, destekleyici ortamların sağlanmasına yönelik olarak mevcut durum incelenmiş ve ilgili konularda eylemler önerilmiştir. Bu raporda belirtilen eylemlerin gerçekleşmesi katılan bütün tarafların etkin katılımları ve çabaları ile gerçekleşeceği ifade edilmiştir (Devlet Planlama Teşkilatı, 2007, s. 10-11).

2013 yllında Türkiye'de Yaşlıların Durumu ve Yaşlanma Ulusal Eylem Planı Uygulama Programı'na ayrıntılı olarak bakıldığında ilk dikkat çeken nokta Yaşlılar ve Kalkınma önceliği altında bulunan yaşlıların karar verme süreçlerine katılımının sağlanmasıdır. Bu konu yerel yönetim birimleriyle ve özellikle de belediyelerle işbirliği içerisinde hareket edilmesi gereken önemli bir husustur. Çünkü kent konseyleri bünyesinde oluşturulacak yaşlı meclisleri bu tür bir görevin uygulanabilmesi açısından bir başlangıç sayılabilir. Yine Yaşlılar ve Kalkınma başlı̆̆ altında yaşlıları aktif işgücünde tutmaya yönelik bir gayret öne çımaktadır. Yaşılıarın çalışma yaşamında aktif rol üstlenmeleri onların psikolojik olarak en azından toplumla bütünleşmelerini sağlayacağına şüphe yoktur. Yaşlılıkta Sağlık ve Refahın Arttırllması önceliği ise yaşlanma ile birlikte ortaya çıkacak sağlık sorunları ve bunların oluşturacağı riskleri en aza indirme hedefleri bulunmaktadır. Sağlıklı yaşlanma bağlamında değerlendirilebilecek bu gayretler doğrudan doğruya yaşam kalitesini artırabilecek özelliktedir. Yaşlılıkta Olanaklar Sunan, Destekleyici Ortamların Sağlanması önceliği ise yaşlılara yönelik gerçekleştirilen bakım hizmetlerinin kalitesine vurgu yapmakla birlikte yaşlıların istismar edilmelerinin engellenmesi, yaşıllara yönelik koruyucu hizmetlerin gerçekleştirilmesi ve yaşlıları günlük hayat içerisinde daha fazla görünmelerine katkıda bulunmalarına yöneliktir (Çolak ve Özer, 2015, s. 120).

I. Yaşlılık Şûrası, Aile, Çalışma ve Sosyal Hizmetler Bakanlığı tarafından 2019 yllında Ankara'da düzenlenmiştir. I. Yaşlılık Şûrası'na yurt içinden ve yurt dışından birçok bilim insanları, uzmanlar, STK ve kamu temsilcileri katılmıştır. Şura'da Aktif Yaşlanma (Sağlıklı Yaşam, Toplumsal Hayata Katılım), Bakım Ekonomisi, Yaşı Bakım Hizmetleri ve Yaşam Kalitesi, Yaşlı Hakları, Yaşlılık Ekonomisi konularında çalışmalar gerçekleştirilmiştir. Türkiye'de yaşlıların ve toplumların mevcut işlevini devam ettirebilmeleri için yaşl1l1k konusunda yürütülecek politika ve programlara ilişkin tavsiyelerde bulunulmuştur. Yaşl1lıkta sık görülen kronik rahatsızlıkların tedavi ve rehabilitasyon hizmetlerinin geliştirilmesi, yaşlıların yaşam kalitelerinin artırlması için çalışmaların yürütülmesi, yaşlıların toplumsal hayata aktif bir şekilde katılımlarının sağlanması amacıyla gönüllülük esasının sağlanması ve sivil topluma katılımın sağlanması konusunda sorunların tespit edilerek gerekli politikaların yürütülmesi, toplumun mevcut ekonomik, sosyal ve kültürel şartları dikkate alınarak en uygun finans yöntemi ile bakım güvence sisteminin yapılması, yaşlılara yönelik olarak uzun süreli bakım hizmetlerinden yararlanma şart ve koşullarının belirlenmesi, gönül belediyeciliği anlayışının yaygınlaştırılarak her bölgede yaşlı dostu kentlerin yaygınlaştırılması, kırılgan bir özellik taşıyan yaşlı insanların, insan haklarından yararlanmalarını sağlayacak pozitif uygulamaların geliştirilmesi çalışmalarının yapılması, yaşlı işgücünün sürdürülebilir istihdamının desteklenmesi amacıyla işgücü piyasası koşullarına uygun becerilerin kazandırılması için gerekli çalışmaların yapılması şeklinde öneriler getirilmiştir (Aile, Çalışma ve Sosyal Hizmetler Bakanlığı, 2019, s. 2-6).

Türkiye'de 2014-2018 yıllarında Kalkınma Planı çalışmaları kapsamında ilk kez Yaşlanma Özel İhtisas Komisyonu oluşturulmuş ve yaşlanma ile ilgili rapor yayımlanmıştır.

Cumhurbaşkanlığı Hükümet Sisteminin ilk kalkınma planı olan On Birinci Kalkınma Planı (20192023), uzun vadeli bir anlayışla ülkenin kalkınmasını ve uluslararası vizyonunu sağlayacak, bakanlıklar başta olmak üzere bütün kamu kurum ve kuruluşlarının yanı sıra toplumun bütün kesimlerinden birçok temsilcinin katılımı ile hazırlanmışır. Planda kamu kuruluşlarının gerçekleştirecekleri politikaları, yatırım, cari harcamalarını, kurumsal ve hukuki düzenlemeleri de kapsayacak şekilde planda hedefler ve kaynaklar ortaya konulmuştur. Planda nüfus ve yaşlanma başlı̆g altında ülkenin genç ve dinamik nüfus yapısının korunması; yaşlıların yaşam kalitesinin artırılması amacıyla ekonomik ve sosyal hayata aktif bir şekilde katılımlarının gerçekleştirilmesi, aktif olarak ve bağımsız bir şekilde yaşamlarını sürdürebilmesi, bakımlarında kalitenin artırılması, sağlı hizmetleri ve ihtiyaç duyacakları diğer hizmetlerden yararlanmalarının ve aktif yaşlanma ortamlarının oluşturulması temel hedef olarak belirlenmiştir. Politika ve uygulanacak tedbirler olarak demografik yapının firsatından yararlanmak için genç nüfusun korunması, uzun süre bakıma ihtiyacı olan yaşlılar için sunulacak hizmetlerin çeşitlerinin arttırılması ve yeni tedbirlerin uygulanması, sürdürülebilir ve kapsayıcı bir bakım sisteminin getirilmesi, evde bakım hizmetlerinin sunumunda farklılıkların ortadan kaldırılarak standartlaşmanın sağlanması, bu konuda yerel yönetim 
birimlerinin daha fazla sorumluluk almalarının sağlanması, evde ve kurumsal yaşlı bakım hizmetlerinde görev alan kişilerin hem nitelik hem de nicelik olarak arttırılması, yaşlılara yönelik olarak etkin sağlık hizmetlerinin sunulması, yaşlıların karşılaşabileceği düşme ve diğer kazaların ortadan kaldırılmasına yönelik olarak gerekli çevre düzenlemelerinin yapılması, yaşlıların ekonomik ve sosyal hayata aktif bir şekilde katılımlarını sağlayacak aktif yaşlanma imkânlarının geliştirilmesi, yaşlıların kendini yalnız ve dışlanmış olarak hissetmeyecekleri ortamların oluşturulması, kuşaklar arasında fikir ve değerlerin geliştirilmesi için uygun ortamların oluşturulması şeklinde tedbirlerin uygulanması hedeflenmektedir (Kalkınma Bakanlığı, 2019, s. 167-168).

Ülkemizde sağlık alanında yaşanan olumlu ilerlemeler, halkın yaşam kalitesinin yükselmesi, daha iyi yaşam koşullarına ulaşma gibi nedenlerden dolayı yaşlı nüfusu gittikçe artmaktadır. Türkiye İstatistik Kurumunun 2019 yılı Adrese Dayalı Nüfus Kayıt Sistemi Veri Tabanına göre toplam nüfusun 41 milyon 433 bin 861 kişisini kadın, 41 milyon 721 bin 136 kişisini de erkek nüfus oluşturmaktadır. Veriler dikkate alındığında ülkemizde toplam nüfusun \% 50,2'sini erkekler, \% 49,8'ini ise kadınlar oluşturmuştur.

Türkiye İstatistik Kurumunun 2019 yllı Adrese Dayalı Nüfus Kayıt Sistemi Veri Tabanına göre ülkemizin toplam nüfusu 83 milyon 154 bin 997 kişiye ulaşmıştır. Veriler dikkate alındığında 65 yaş üstü kişilerin toplam nüfusa oranı yaklaşı \% 9,1 olduğu görülmektedir. Ülkemizde yaşlı nüfusun arttı̆̆ görülmektedir.

Ülkemizde yaşlılara yönelik olarak uygulanan yatılı kurum hizmetleri SHÇEK'e bağlı olarak hizmet veren Huzurevleri ile Huzurevi Yaşlı Bakım ve Rehabilitasyon Merkezleri ile Özel Huzurevleri ve Yaşlı Bakım Merkezleri ve Diğer Kamu Kurum ve Kuruluşları bünyesinde açılan Huzurevleri aracıllğı ile yürütülmektedir.

Huzurevleri İle Huzurevi Yaşı Bakım ve Rehabilitasyon Merkezleri, 60 yaş ve üzerindeki sosyal ve ekonomik yönden bakıma ihtiyaç duyan yaşı bireylerin, her yönden bakımlarını sağlamak, kendi ihtiyaçlarını kendileri sağlayanlara gerekli psikolojik ve sosyal desteğin verildiği; kendi ihtiyaçlarını karşılayamayacak durumda olanların ise sürekli olarak bakımlarının sağlandığı sosyal hizmet birimleridir. Bu birimlerde, yaşlı bireylerin boş zamanlarını etkili bir şekilde geçirmelerini sağlamak amacıyla aktiviteler düzenleme, psikolojik olarak sorunlarının giderilmesini sağlama, beslenme, barınma gibi temel ihtiyaçlarının karşılanması gibi hizmetler sunulmaktadır. Bu birimlerin daha çok şehir merkezlerine ve sağlık kuruluşlarına yakın yerlerde kurulmasına dikkat edilmektedir. SHÇEK Genel Müdürlüğüne bağlı olarak hizmet veren huzurevlerinde yaşayan 60 - 65 arasındaki yaşı bireylere 2022 sayılı kanun gereği olarak aylık 97 TL harçlık verilmektedir. 65 yaş ve üzerindeki huzurevlerinde ücretsiz kalan yaşlı bireylere 2022 saylı kanun gereği olarak üç ayda bir SGK tarafindan 291 TL verilmektedir.

\section{Dünyada Yaşlılara Yönelik Sosyal Hizmet Uygulamaları}

Yaşanan sosyo-ekonomik değişimler, ortaya çıkan dünya savaşları, kabul edilen ideolojilerin toplumları değiştirmesi sonucu yaşlilara karşı gösterilen tutumlarda da değişimler olmuştur. Sanayileşmiş toplumlarda geleneksel toplumlara nazaran daha fazla çekirdek ailenin ve nüfus hareketlerinin olduğu görülmektedir. Yapılan araştırmalar yaşanılan modernleşme ve kentleşmenin yaşlının statüsünü derinden etkilediğini göstermiştir (Özürlü ve Yaşlı Hizmetleri Genel Müdürlüğü, 2013, s. 3).

Yaşlılıkla ilgili yapılan düzenlemelerden 1948 yllında kabul edilen "İnsan Hakları Evrensel Bildirgesi"nin 25. maddesine göre herkesin yeterli yaşam standardı hakkına sahip olduğunu ve bu hakkın kendi iradesi dışında kaynaklanan işsizlik, hastalık, sakatlık, yaşlılık gibi dönemlerde geçimini sağlayamama gibi durumlarda güvenlik hakkını da kapsadığı belirtilmiştir. Diğer önemli bir düzenleme 1982 yılında Viyana'da yaşlanma ile ilgili politikaları belirlemek amacıyla 1. Yaşıllık Asamblesi düzenlenmiştir. Bağımsız yaşam, katılımcılık, bakım, onurlu yaşam ve kendini gerçekleştirme şeklinde beş öneri sunulmuştur. 2002 yllında Birleşmiş Milletler tarafindan Madrid'de düzenlenen 2. Yaşllık Asamblesinde ise, yaşlı nüfusun yaşam kalitesinin iyileştirilmesi, topluma uyumları, geçim ve sağlık problemleri ve bütün yaş gruplarını kapsayacak politikalar oluşturulması amacıyla "Uluslararası Eylem Planı" hazırlanmıştır. Binyıl Bildirgesi, yaşlılara özgü özel bir düzenleme içermemesine karşın, Binyıl Kalkınma Hedefleri arasında "2015 yilına kadar yoksulluk içinde yaşayan insanların oranının yarıya indirilmesi” amacı yoksulluğu azaltmak amacıyla yaşlılarla ilgili konuların düzenlenmesini de kapsamaktadır. Ayrıca, yaşlanma konusuna daha fazla ilgi uyandırmak amacıyla Birleşmiş Milletler tarafindan 1999 yılı Yaşlılar Yılı olarak ilan edilmiştir (Özürlü ve Yaşlı Hizmetleri Genel Müdürlüğü, 2013, s. 5-6). 
Yaşlanma 2002 Uluslar arası Eylem Planı'na göre, yirmi birinci yüzyılda yaşanan hızlı yaşlanma süreci sonucunda ortaya çıkabilecek sorunların giderilmesi amacıyla bütün sektörlerin tamamında her düzeyde davranış, uygulama ve politika konusunda değişikliklerin yapılması zorunlu görülmektedir. Aslında, dünyada birçok ülkede, birçok yaşlı güvenli bir ortamda saygın bir şekilde yaşlanmakta, aile ve toplum olarak gerçekleştirilen faaliyetlere aktif bir şekilde katılabilmektedir. Eylem Planı'nın amacı, bütün toplum ve mekânda insanların güvenli ve saygın şekilde yaşlanmalarını ve yaşadıkları toplumlarda bütün haklara sahip birer birey olarak hayatlarını sürdürmelerini garanti altına almaktır. Sağlıklı ve güçlü bir yaşlılık döneminin temelleri hayatın ilk yıllarında başladığı anlayışından hareket edilerek; bireysel ve toplumsal yaşlanmanın sağlanması amacıyla bu konular üzerinde durulmasını sağlamak için politikacılara yol gösterici olması hedeflenmiştir. Yaşlanma sürecinde ortaya çıkan özellikler ve sorunlar dikkate alınarak ülkelerde ortaya çıkabilecek bu çok farklı durumlara uygun öneriler geliştirilmiştir. Plan'da, bölgesel düzeyde yaşanan değişimler, bölgeler arasında yaşanan kalkınma farklılıkları ve küreselleşmenin etkisiyle ülkelerin birbirine bağımlılığı da dikkate alınmaktadır. Uluslararası Yaşlılar Yılı olarak kabul edilen 1999 yilının ana teması "bütün yaşlar için bir toplum" dört önemli hususu içermektedir: yaşam boyu bireysel gelişme, kuşaklar arası ilişkiler, toplum yaşlanması ve kalkınma ilişkisi ile yaşlıların durumu. Uluslararası Yaşlılar Yıll, bütün sektörlerde yaşlanma konusuna önem verilmesine, hayatın bütün aşamalarında sunulan imkânların artırılmasına, bütün dünya ülkelerinde bu durumun farkında olmalarına, bu konuyla ilgili yapılacak araştırma ve politikaların artırılmasına katkıda bulunmuştur (GEBAM, 2002, s. 7).

Yaşlanma ile ilgili Uluslararası Eylem için getirilen öneriler; yaşlıların, kalkınma sürecine tam olarak katılması sağlanmalı ve kalkınmadan aynı şekilde yararlanmalıdır. Hiçbir birey, kalkınmadan yararlanma konusunda bir kısıtlama ile karşılaşmamalıdır. Toplumlarda nüfusun yaşlanması ile yaşanan sosyoekonomik değişimler ülkelerin yaşlıların güçlendirilmesi ve sosyal hayata aktif katılımlarını sağlayacak acil düzenlemelerin yapılması gerektiği ortaya çıkmıştır. Bütün yaşlar için bir toplum anlayışı ile çalışma hayatında yaşlılara yönelik her türlü ayrımcılığın ve dışlanmanın ortadan kaldırılması gerekmektedir. Yaşlıların aile üyeleri için ekonomik aktivitelerden daha çok sosyal ve ekonomik katkıları daha fazladır. Yaşlıların sosyal, kültürel, ekonomik ve politik katılımlarının tanınması amacıyla yaşlıların bütün insan hakları ve temel özgürlüklerden tam olarak yararlanmasının sağlanması gerekir. Yaşlıların karar verme sürecinin bütün aşamalarına katılımının sağlanması amacıyla karar verme sürecinde yaşlıların temsil edilmeleri için, karar vermenin bütün aşamalarında yaşlı organizasyonlarının kurulmasının teşvik edilmesi gerekir. Yaşlıların kendi istedikleri ve verimli bir şekilde yapabildikleri süre içerisinde, ekonomik kazanç sağlayan işlerde çalışmalarını sürdürmeleri için gerekli imkânlar sağlanmalıdır. Çalışmak isteyen bütün yaşlılar için istihdam olanaklarının sağlanması amacıyla iş hayatı ile ilgili düzenlenecek politikaların bütün yaş grubundaki kişilerin yararı gözetilerek istihdam ortamının yaratılması gerekir. Kırsal kesimde kalkınma, göç ve kentleşme gelişmekte olan ve geçiş sürecinde olan birçok ülkede gençlerin göç etmesi sonucu kırsal kesimde yaşlı nüfusun fazla olduğu dikkat çekmektedir. Yaşlılar bazı bakım, gelir desteği gibi bazı durumlarda sıkıntı yaşayabilirler. Bu yüzden beslenme ve tarım ile ilgili politikaların düzenlenmesi sırasında yaşlıların göz önünde bulundurulması gerekir. Kırsal kesimde yaşam koşullarının ve alt yapinın iyileştirilmesi amacıyla tarım sektöründe çalışan yaşlıların güçlendirilmesi amacıyla yeni tarım tekniklerinin ve teknolojilerinin öğretilmesi, yaşlıların yapısal ve finans hizmetlerine ulaşılabilirliğin sağlanması gerektiği şeklinde öneriler getirilmiştir (GEBAM, 2002, s. 9-13).

Yaşlanan toplumun taleplerini karşılamak için temel sağlık ve sosyal konularda, sağlık alışkanlıklarının teşvik edilmesi, sağlık durumunun izlenmesi, tedavi edilmesi konularında sosyal hizmetler ve tıbbi hizmetlerin dönüşeceği beklenmektedir. Ölüm oranı, sağlık ve yaşlanma arasındaki değişikliklerin yaşlılık algisı üzerinde güçlü bir etkiye sahiptir. Son yıllarda tüm bölgelerde ortalama yaşam beklentisi artmışırı (Buches, 2014, s. 32).

Dünyada yaşlılara yönelik olarak evde bakım hizmeti, öz bakım, hemşire bakımı, rehberlik hizmetleri, yaşlıların evlerine yemek servisleri, yaşlılara gündüz hizmet veren dayanışma merkezleri hizmetleri sunulmaktadır. Ayrıca sürekli olarak tek başına yaşayamayan yaşı bireylere yönelik olarak huzurevleri, bakımevleri, yaşı apartmanları hizmetleri verilmektedir. Yaşlı apartmanlarında tek başlarına ihtiyaçlarını karşılayabilen yaşlılar bulunurken, huzurevleri ve bakımevlerinde tek başlarına ihtiyaçlarını karşılayamayacak durumda olan yaşlılar kalmaktadır. Bakımevleri ve huzurevleri arasında belirgin bir farklılık bulunmamakla birlikte, bakımevlerinde daha çok hastanede verilen hizmete yakın hizmet sunumu gerçekleşmektedir. Bunların yanı sıra Avrupa'da yaşlılara yönelik olarak birçok farklı hizmetler de verilmektedir. Yaşlılara yönelik koruyucu aile hizmetleri, ev idaresi hizmetleri, bazı tatil imkânlarının 
sunulması, yaşlılara yönelik olarak özel yayınların sunulması, yaşlılara yönelik danışma, eğitim ve bilgi hizmetleri şeklinde hizmetler verilmektedir (Koşar, 1996, s. 199).

Yaşlılara yönelik hizmet veren kuruluşların sayılarında nicelik olarak bir artış söz konusu olurken; hizmet kuruluşlarının nitelik olarak özelliklerindeki artış yeterli düzeyde gelişmemiştir. Son dönemde yaşlıların bakımında ailelerin yetersiz kalması, çevresinin bakımının eksik kalması gibi durumların artmasıyla birlikte yaşıllara yönelik hizmet veren kuruluşlar, daha kaliteli ve etkili hizmetler sunmaya başlamışlardır. Yaşlı bireylerin gittikçe artan bakım sorunları onların daha sağlıklı bir hayata sahip olmalarını ve sosyal hayata kazandırılmalarını önemli hale getirmektedir. Bu bakımdan yaşlılara yönelik olarak sunulan sosyal hizmetlerin nitelik ve nicelik yönünden artırılması, yeni hizmetlerin sunulması, yaşlıların kendi ortamlarında ihtiyaçlarının karşılanması önem arz etmektedir (Şeker ve Kurt, 2018, s. 2021).

ABD'de yaşlılara yönelik olarak geriatri hastaneleri, hastanelerde geriatri bölümlerinin açılması, bakım yurtları ve diğer sağlık kuruluşları hizmet vermektedir. Yaşlılara hizmet veren bakım yurtları, yaşılların bakımlarını sağlayan, bir uzmanlığa dayalı olarak bakımlarını gerçekleştiren önemli kurumlar olarak varllğını sürdürmektedir. Kısmen uzmanlaşmaya dayalı olarak hizmet veren bakım yurtları yaşlların bakımlarını sağlama konusunda bazı durumlarda uzmanlaşmış tedavilerin de verildiği kurumlar olarak hizmet sunmaktadır. İngiltere'de ise yine uzun ve kısa süreli hizmet veren geriatri hastaneleri ile hastanelerde geriatri bölümleri yaşlılara yönelik olarak hizmet vermektedir. Ayrıca geriatri alanında uzman hekimler yaşlıların evlerine ziyaretlerde bulunmaktadır. Özellikle geriatri hastanelerinde ve geriatri bölümü bulunan hastanelerde yaşlılara yönelik sosyal hizmetler ofisi de hizmet vermektedir. Bakım yurtları, özellikle kronik hastalı̆̆ı olan yaşlılar, hastalıkları uzun süre yatmalarını gerektiren yaşlılar ve tıbbi olarak hastanelerde gerekli bakımı aldıktan sonra dinlenmeleri gereken yaşlılar için önemli bir hizmet sunmaktadır. Bakım yurtları sayesinde hem hastanelerin yoğunluğu azaltılmış olmakta hem de yaşlılar uzman hekimler tarafindan gözetim altında bakılmaktadır. Yaşlılar evlerinde yaşıyorlar ise bu kişilere evde sağlık hizmetleri sunulmaktadır. İngiltere'de ev sağlık hizmetleri gelişmiş seviyededir. İsteyen yaşliya evde doktor hizmeti sunulmakta ve evinde tıbbi bakım hizmeti gerçekleştirilmektedir. Bu noktada gönüllü kuruluşlar önemli rol oynamaktadır. ABD ve İngiltere'de yalnız kalan ya da çift olarak kalan yaşlılara bağımsız katlar ya da küçük evlerden oluşan bakım kurumları şeklinde hizmetler verilmektedir. Bu bakım kurumları ya yerel yönetim birimleri tarafindan ya da konut birlikleri tarafindan yaşllara kiralama şeklinde verilmektedir. Uygulamada adı korumalı ev-korumalı daire olarak geçmektedir. Ayrıca bakım kurumlarında sosyal hizmet sunumu yapılmaktadır. Bunun yanında İngiltere'de bakımevlerinden başka sürekli olarak bakıma ihtiyacı olmayan yaşlılar için huzurevleri de hizmet vermektedir. ABD, İngiltere, Almanya ve İskandinav ülkelerinde yaşlilara yönelik olarak hizmet veren kurum ya da kuruluşlar kurumsallaşmış ve toplum tarafindan kabul görmüştür. Gündüz evinde yalnız kalamayan yaşlılar için gündüz bakımevleri hizmet vermektedir. Gündüz bakımevlerinde yaşlıların hem yemek ihtiyaçları karşılanmakta, ilaçlarını almaları sağlanmakta hem de birbirleri ile sosyal olarak vakit geçirmelerine imkân tanımaktadır (Aydın, 2005, s. 3-4).

\section{Türkiye'de Yaşlılara Yönelik Sosyal Hizmet Uygulamaları}

Dünya Sağlık Örgütü 60 yaş ve üzeri kişi sayısının 2000 yılı ile 2050 yılları arasında iki katına ulaşacağını tahmin etmektedir. Diğer bir ifade ile 2050 yılında her beş kişiden birinin 60 yaşında y ada üzerinde olacağı ifade edilmektedir. Bu bakımdan gelişmiş ülkelerde olduğu gibi ülkemizde de hızla artan yaşlı nüfusa yönelik sunulacak sosyal hizmet uygulamaları önem kazanmaktadır (Yerli, 2017, s. 1278).

Yaşlılara yönelik olarak üretilecek olan politikalar, sosyal politika alanında belki de en önemli konu başlıklarından birini temsil etmektedir. Dünya genelinde belirgin bir şekilde yaşlıların sayısal olarak artması yaşlılara yönelik olarak sosyal politika alanlarına daha fazla özen gösterilmesi gereğini ortaya çıkarmıştır. Yaşlılık dönemi insanlar için kaçınılması mümkün olmayan bir süreci anlatmaktadır. Aynı zamanda bu dönemin kendine özgü bazı özellikleri ile karşılaşmaması mümkün görünmemektedir. Bu noktada yaşlıların, yemek yeme, zorunlu ihtiyaçlarını karşılama, alışveriş yapma, toplumla ilişki kurma, sokağa çıkma, yürüyebilme gibi konularda desteklenmeleri konusu dikkat çekmektedir. Yaşlilara yönelik sosyal politikalar, bu desteklemenin somut "sosyal" yönü şeklinde kabul edilebilir. Bu kapsamda, bakım hizmetleri, sosyal hizmetler, sosyal yardımlar ve çeşitli emeklilik sistemleri yolu ile yaşlilara yönelik olarak sosyal politikalar düzenlenmekte ve uygulanmaktadır.(Tuncel ve Uzun, 2019, s. 322).

Yaşlılara yönelik olarak sosyal politikaların oluşturulması sürecinde demografik faktörler büyük önem taşımaktadır. Birinci ve İkinci Dünya savaşlarında çok sayıda genç nüfusun ve yetişkin nüfusun yaşamını 
yitirmesi sonucu yaşlı nüfus artmış, yaşlı nüfusun toplam nüfus içerisindeki oranının artmasına neden olmuştur. Teknoloji ve tıp alanında yaşanılan değişim ve gelişimler, insanların yaşam koşullarında iyileşmeler sağlamış ve bu gelişmeler sonucunda insanların ortalama yaşa süresi uzamıştır. Toplumsal yapıda yaşanan değişim ile aile yapısında dönüşümlerin yaşanmasını ortaya çıkarmıştır. Geleneksel geniş aile yapısı gittikçe yerini çekirdek aile yapısına bırakmış, bu aile yapısı sonucunda aile bağları zayıflayarak yaşlıların ailelerinin içerisindeki konumları değişime uğramıştır. Yaşlılara yönelik olarak düzenlenen sosyal politikaların temelini oluşturan diğer önemli husus ise sosyal devlet anlayışıdır. Sosyal devlet anlayışını kabul eden ülkeler, bu anlayış doğrultusunda yaşlılara yönelik olarak sosyal politika alanları düzenlemeye başlamışlardır. Yaşlı politikaların oluşturulmasında diğer önemli etken hümanistik yaklaşımdır. Yaşlanma süreci doğal insani bir süreç olduğundan hareketle, bu süreçte ortaya çkabilecek sorunları azaltacak ya da ortadan kaldıracak kurumların oluşturulması insani bir hareket olarak kabul edilmektedir (Umutlu ve Tekin-Epik, 2019, s. 40).

Dünyada ve Türkiye'de yaşlılara yönelik uygulanan sosyal politikalar söz konusu olduğunda kuşkusuz ilk akla "emeklilik sistemleri" gelmektedir. Daha sonra yaşlıların çalısma hayatında karşılaşabilecekleri sosyal dışlanma, ayıımcılık gibi sorunların yaşanmaması amacına yönelik olarak uygulanan sosyal politikalar akla gelmektedir. Ayrıca yaşlılara yönelik olarak sunulan sosyal hizmetler ve sosyal yardımlar yaşlilara yönelik uygulanan sosyal politikaların önemli adımlarını oluşturmaktadır (Taşcı, 2010, s. 183).

Özellikle son ylllarda dünyada ve Türkiye'de ortalama yaşam süresinin artmasıyla birlikte yaşlı nüfusunda bir artış söz konusudur. Dolayısıyla yaşlılara yönelik sunulan hizmetler gün geçtikçe daha önemli hale gelmektedir. Ülkemizde yaşllara yönelik olarak hizmet veren kurumların en başında Aile, Çalışma ve Sosyal Hizmetler Bakanlığı gelmektedir. Yaşlılara yönelik sunulan bütün hizmetleri tek bir çatısı altında toplamaktadır. Yaşlılara yönelik uygulanacak ulusal ve uluslararası bütün proje, politika ve prosedürlerin uygulanmasını, yürütülmesini, denetimini gerçekleştirmektedir. Bakanllğa bağl olarak Sosyal Yardımlar Genel Müdürlüğü ve Engelli ve Yaşlı Hizmetleri Genel Müdürlüğü yaşlılara yönelik olarak hizmet veren diğer önemli kuruluşlardır. Ayrıca "Huzurevleri ile Huzurevi Yaşlı Bakım ve Rehabilitasyon Merkezleri”, "OOzel Huzurevleri ile Yaşlı Bakım Merkezleri” ve "Yaşlı Hizmet Merkezleri Gündüzlü Dayanışma Hizmetleri”" ile bakıma muhtaç yaşlılara yönelik sosyal hizmet verilmektedir. Yaşlılara yönelik hizmet veren kurumsallaşma anlamında en önemli kurumlar "Huzurevleri" ve "Huzurevi Yaşlı Bakım ve Rehabilitasyon Merkezleri” bulunmaktadır. Aile, Çalışma ve Sosyal Hizmetler Bakanlığı, Huzurevleri ve Huzurevi Yaşlı Bakım ve Rehabilitasyon Merkezleri kapsamında yaşlılara sosyal hizmet sunmaktadır.

Ülkemizde yaşlılara yönelik olarak sunulan önemli sayllacak hizmetlerden birisi de "Özel Huzurevleri ile Yaşlı Bakım Merkezleri” aracılığı ile yaşlılara sunulan hizmetlerdir. Bu kuruluşlarda 55 yaş ve üzerinde olan ekonomik ve sosyal yönden bakıma ihtiyaç duyan kişilerin bakımları sağlanmaktadır. Ülkemizde uygulama alanı bulunan diğer bir hizmet "Gündüzlü Bakım Hizmetleri" ve "Evde Yaşama Destek Hizmetleri” sunulmaktadır. Akıl ve ruh sağlığı yerinde olan yaşlıların zamanlarını daha kaliteli geçirmek adına birtakım sosyal etkinliklerin sunulduğu, danışmanlık hizmetlerinin verildiği merkezler olarak karşımıza çıkmaktadır. Aile, Çalışma ve Sosyal Hizmetler Bakanlı̆̆ kapsamında yaşlılara yönelik olarak sunulan kurumlardan bir tanesi de "Yaşlı Dayanışma Merkezleri”" olarak uygulama alanı bulmaktadır. Bu uygulama merkezleri 2008 yılında yapılan bir değişiklik ile "Yaşlı Hizmet Merkezi" adını alarak yaşlılara yönelik sosyal hizmet sunumu yapılmaktadır.

Aile, Çalısma ve Sosyal Hizmetler Bakanlığı’na bağlı olarak faaliyet gösteren Sosyal Yardımlar Genel Müdürlüğü, sosyal yardımları daha etkin ve hızlı bir şekilde organize edebilmek adına Sosyal Yardım Bilgi Sistemi (SOYBİS), Bütünleşik Sosyal Yardım Hizmetleri (BSYH) ve ALO144 Sosyal Yardım Hatt projelerini yürütmektedir.

Tablo 6. Bakanliğımıฉ̨a Bağh Huұurevi Sayısı, Kapasitesi ve Huzurevlerinde Kalan Yaşlı Birey Sayısımn Yillara Göre Dağzllm

\begin{tabular}{cccc}
\hline Yillar & Huzurevi Say1S1 & Kapasite & Bak1lan Yaşl1 Say1s1 \\
\hline 2020 (Şubat) & 153 & 15.607 & 13.970 \\
2019 & 153 & 15.385 & 13.888 \\
2018 & 146 & 14.967 & 13.883 \\
2002 & 63 & 6.477 & 4.952 \\
\hline
\end{tabular}

Kaynak: Engelli ve Yaşlı Hizmetleri Genel Müdürlüğü 
Tablo 6'da 2002 yılından itibaren Aile, Çalışma ve Sosyal Hizmetler Bakanlığı'na bağlı huzurevi sayısı, huzurevlerinin kapasitesi ve huzurevlerinde kalan yaşlı birey sayısının yıllara göre dağılımı yer almaktadır. 2002 y1lında huzurevi sayısı 63 iken, 2020 yılında Şubat ayında 153'e yükselmiştir. Bakılan yaşlı sayısı ise, 2002 yilında 4.952 kişi iken 2020 yilında Şubat ayında 13.970'e ulaşmıştır. 2002 y1lı ile 2020 (Şubat) y1lları dikkate alındığında huzurevi sayısı, huzurevlerinin kapasiteleri ve bakılan yaşlı sayısı yaklaşık 2,5 kat bir artış söz konusudur.

Tablo 7. Kamu, Öz̨el, Diğer Kamu Kuruluşlarna Ait Huzurevleri Sayısı, Kapasiteleri ve Bakılan Yaşl Sayısı

\begin{tabular}{lccc}
\hline Yatılı Bakım Huzurevleri 2020 Şubat & Huzurevi Sayısı & Kapasite & Bakılan Kişi Sayısı \\
\hline Bakanlı̆̆ımıza Bağlı Huzurevleri & 153 & 15.607 & 13.970 \\
Bakanlığımıza Bağlı Darülaceze (Yaşlı) & 1 & 503 & 458 \\
Diğer Kamu Kuruluşlarına Ait Huzurevleri & 25 & 3.504 & 2.432 \\
Özel Huzurevleri & 247 & 16.089 & 10.715 \\
TOPLAM & 426 & 35.703 & 25.575 \\
Bakanlığımıza Bağlı Huzurevleri Kapasitesine Dahil & 29 & 125 & 122 \\
Olan Yaşlı Yaşamevleri & & & 301 \\
Gündüz Hizmet Veren Kuruluşlar & 30 & 457 & \\
\hline
\end{tabular}

Kaynak: Engelli ve Yaşlı Hizmetleri Genel Müdürlüğü

Tablo 7'de 2020 (Şubat) yılında kamu, özel, diğer kamu kuruluşlarına ait huzurevleri sayısı, kapasiteleri ve bakılan yaşlı sayısı yer almaktadır. Bu verilere göre 2020 yılında Bakanlığımıza bağlı olarak hizmet veren huzurevleri sayıs1 153'tür. 247 tane de özel huzurevleri hizmet vermektedir. Toplam bakılan yaşlı sayısı 25.575 kişi iken; 13.970 kişinin Bakanlığımıza bağlı olarak hizmet veren huzurevlerinde bakım hizmeti almakta iken, 10.715 kişinin özel huzurevlerinde bakım hizmeti aldığ1 görülmektedir. Bakanlığımıza bağlı olarak hizmet veren huzurevleri kapasitesine dahil olan yaşlı yaşamevleri 29'a ulaşmıştır. 30 gündüz hizmet veren kuruluşların hizmet verdiği kişi sayısı 301 kişiye ulaşmıştır.

Tablo 8. Engelli ve Yaşlı Hiæ̣metleri Genel Müdürlügü Yaşh Bakım Hiæmetleri Kapsamında Yul Sonu Itibariyle Harcanan Ödenek Miktar

\begin{tabular}{lc}
\hline Yillar & Yl Sonu İtibariyle Harcanan Ödenek Miktar1 (Milyon TL) \\
\hline 2019 & 904,1 \\
2018 & 776,1 \\
2017 & 625,1 \\
2016 & 497,7 \\
2015 & 367,1 \\
2014 & 313,9 \\
2013 & 291,4 \\
2012 & 253,9 \\
\hline
\end{tabular}

Kaynak: Engelli ve Yaşlı Hizmetleri Genel Müdürlüğü

Tablo 8'de 2012 y1lı ile 2019 y1lları arasında Engelli ve Yaşlı Hizmetleri Genel Müdürlüğü yaşlı bakım hizmetleri kapsamında y1l sonu itibariyle harcanan ödenek miktarı yer almaktadır. 2012 y1lında harcanan tutar 253,9 Milyon TL iken 2019 yılında 904,1 Milyon TL’ye ulaşmıştır. Yıllara göre harcanan ödenek miktarına dikkat edildiğinde sürekli olarak harcanan ödenek miktarı artış göstermiştir.

Tablo 9. Yaşlı Maaşı Alan Kişilerin ve Ayrlan Kaynak Miktarının Yıllara Göre Dağılımı

\begin{tabular}{ccc}
\hline Yillar & Kisi Say1s1 & Tutar (Milyon TL) \\
\hline 2020 (Şubat) & 755.900 & - \\
2019 & 805.432 & 5.574 \\
2018 & 709.590 & 2.900 \\
2014 & 629.590 & 1.009 \\
2010 & 848.826 & 1.059 \\
2002 & 746.468 & 234 \\
\hline
\end{tabular}

Kaynak: Sosyal Yardımlar Genel Müdürlüğü

Tablo 9'da 2002 yılından 2020 (Şubat) yılına kadar yaşlı maaşı alan kişilerin ve ayrılan kaynak miktarının dağılımı yer almaktadır. Verilere göre, 2002 yılında yaşlı maaşı alan kişi sayısı 746.468 iken, 2020 (Şubat) yılında yaşlı maaşı alan kişi sayısı 755.900 kişiye ulaşmıştır. 
Yerel yönetim birimlerinden belediyelerin sosyal politika uygulamaları; yardıma muhtaç olan yaşlı bireylerin güvenli bir şekilde barınmalarının sağlanması için huzurevi yapmak, ihtiyacı olan bireylere ücretsiz muayene ve ilaç yardımı yapmak, gıda, yakacak, ev temizliği hizmetlerine destek olmak, yardıma muhtaç olan ya da yaşlı bireylere yönelik belediye otobüslerinden ücretsiz veya indirimli yararlanmalarını sağlamak gibi önemli görev ve sorumlulukları bulunmaktadır. Ekonomik ve kültürel düzeyde gelişmiş belediyeler ise, bireylere yönelik olarak seminer ve poliklinik hizmetleri, aşevinden evlere yemek dağıtımı, nakdi yardım, ihtiyaç halinde ambulans ile evden sağlık hizmeti vermek, özel gün kutlamaları gerçekleştirmek, sinema ve tiyatro etkinlikleri düzenlemek, davetlere katıllımları sağlanmak ve gezi programları düzenlenmek gibi önemli sorumlulukları bulunmaktadır. Ancak belirtilen bu görevlerin birçoğu, daha çok Büyükşehir Belediyeleri ile nüfus ve gelişmişlik düzeyi bakımından büyük olan il ve ilçe belediyeleri tarafindan yerine getirilmektedir. Büyükşehir, ilçe ve ilk kademe belediyelerinin yerine getirecekleri görev ve sorumlulukları kanunlarda düzenlenmiştir. Belediyeler ise yasal olarak, sağlık merkezleri açmak, hastaneler, gezici sağlık birimleri ile yetişkinler, yaşıllar, engelliler, kadınlar, gençler ve çocuklara yönelik olarak her türlü sosyal ve kültürel hizmetleri gerçekleştirmek, bu konularda verilecek hizmetlerin geliştirmesini sağlamak ve bu maksatla sosyal tesisler kurmak, yetişkinler, yaşlılar, engelliler, kadınlar, gençler ve çocuklara yönelik olarak meslek ve beceri kazandırma kursları açmak ve bu kursların işletilmesini sağlamak ve bu hizmetleri yerine getirirken diğer kamu kurum veya kuruluşları ile işbirliği yapmakla yükümlü kılınmıştır (Aile ve Sosyal Pol. Bak. Ulusal Eylem Planı, 2013). Yaşlılara yönelik olarak yerel yönetimlerin sosyal politika uygulamaları dikkat çekmektedir.

\section{Türkiye’de Yaşlıların Sorunları ve Çözüm Önerileri}

Yaşlıların bağımlı ve bakıma muhtaç olarak algılanması, yaşlıların ilgilenilmesi gereken, bağımlı, sağlıksız ve bakıma muhtaç insanlar olarak kodlanması anlamına gelmektedir. Bakıma ihtiyacı olan yaşlı insanlar mutlaka bulunmaktadır ancak 60 ya da 70 yaşın üzerinde bulunan birçok insanın kimseye bağlı olmadan aktif bir şekilde günlük hayatını devam ettirdiği görülmektedir. Bu insanların bazılarının kendi çocuklarına ve diğer aile üyelerine hem maddi hem de manevi yönden destek olabilmesi de halâ söz konusu olabilmektedir. Ancak güçlü bir şekilde kabul gören şey, bu insanların bakıma muhtaç olarak algılanmasıdır. Kimi zaman yaşlıların yaşamış olduğu sıkıntılı durumlardan birisi de muhatap almama durumudur. Yaşlı bireylere genellikle çocuk muamelesi yapılmaktadır. Çocukların henüz duygusal ve gelişimsel yönden erişkin olmadıkları için yetişkinlere davranıldığı gibi davranılmaması kimi zaman doğal karşılanabilir. Ancak yetişkin bir bireye çocuk gibi davranılması yetişkin birey açısından küçültücü bir davranış olarak algılanmasına neden olabilir. Türkiye'de belirli bir yaşın üzerine gelen bireylerin 'bey' ya da 'hanımefendi' hitaplarını kaybederek 'amca', 'teyze' ya da 'nine' statüsüne kavuşturulduğu görülür. Yaşlı bireylerin yaşamış oldukları diğer bir sıkıntı sosyal hayattan dışlanmadır. Belli bir yaşın üstüne gelmiş insanlar toplumda "yaşlı" olarak algılandıkları için kim zaman sosyal hayata katılım konusunda birtakım sıkıntılarla karşılaşabilmektedir. Bunun birçok yolu olabilir; örneğin otobüslere insanların rahat bir şekilde inip binmeleri konusunda bazen otobüslerin çok yüksek olması gibi uygun toplu taşıma araçlarının kullanılamaması gibi. Yaşlı bakımevlerinde yaşayan yaşılıarın sosyal hayattan izole bir hayat sürmesi bir sosyal dışlanmaya örnek gösterilebilir. Başka bir yol da toplum ve akranlar tarafindan gelen baskılar olabilir. "Yaşlı" insanların belli bir yere gitmeleri (örneğin bir konser, bir tiyatro gibi), belli bir kıyafet giymenin, çalışma hayatlarına devam etmek istemeleri ya da evlenmek istemeleri çevreleri tarafindan ayıplanmalarına örnek gösterilebilir. Yaşlıların yaşamış oldukları bir diğer sıkıntılı husus suiistimal edilmeleridir. 'Yaşlı' bireyler birçok yönden suiistimal edilebilirler; cinsel, fiziksel ya da finansal yönden herhangi bir zarara uğratılabilirler. Örneğin 'yaşlı' bireyler miras konusunda yakın ailesinin psikolojik baskılarına maruz kalabilirler. Kimi zaman basında görülen yalnız yaşayan yaşlı insanların bu tür sıkıntıları yaşadıkları haberleri suiistimal örneği olarak gösterilebilir (Çayır, 2012, s. 5-6).

$\mathrm{Bu}$ yüzden insanların yaşlılık sürecine uyumlarının sağlanması, yaşlı insanların topluma katılımlarının arttırılması, onların yaşam memnuniyeti duygularını da yükseltecek olan çeşitli aktivitelerin geliştirilmesi önemli bir konudur. Bu kapsamda, düzenlenen aktif yaşlanma stratejileri ile geliştirilen sosyal politikaların oluşturulması ve standartların belirlenerek uygulanması, yaşlanma sürecinin sebep olduğu negatif anlayışı olumluya çevirecek ve yaşı insanların sahip oldukları birikimlerden genç kuşağın faydalanmasını sağlayacak bir mekanizmanın oluşturulması gerekir (Çolak ve Özer, 2015, s. 118).

Yaşlı nüfus, sosyo-ekonomik ve sağlık sonuçları bakımından önemlidir. Yaşlı nüfus özellikle artan sağlık yükü anlamına gelmektedir. Yaşıı nüfus, sosyal sigortayı özellikle emeklilik sistemini etkilemektedir. Yaşlı nüfus ekonomik büyüme, ticaret, göç, hastalıkların çeşitlerini ve yayılması gibi temel varsayımları 
etkilemektedir. Bilimsel kanıtları bulunmasına rağmen nüfusun yaşlanmasının önemi ve küresel etkileri konusunda henüz tam olarak kabul edilmemektedir (Vepachedu, 2019, s. 1).

Başlangıçta nüfusun yaşlanması toplum için bir sorun değildi. Nüfusun yaşlanması sebep olan faktör iken; doğurganlı̆̆n azalması da çözümünü oluşturmaktadır. Ekonomik büyüme üzerinde olumlu etkileri bulunmaktadır. Nüfus artış oranlarındaki düşüş arttıkça her bir çalışanı korumak için daha az çıktının belli bir sermaye ile yatırıma tahsis edilmesi gerekir. Bu nedenle nüfus artışının yavaşlaması ekonomi üzerinde olumlu etki olarak kabul edilmektedir. Ancak daha uzun vadede doğurganlık oranları daha düşük bir seviyede dengelendiğinde, ölüm oranı gençleşmeden sonra nüfusun yaşlanmasına geçtiğinde, yaşlıların nüfus içindeki payı sadece artmaya devam etmiş; ancak bağımlılık oranı da artmıştır (Bengtsson ve Scott, 2010, s. 10).

Türkiye'de geleneksel aile içerisinde yaşlı insanın konumu her zaman çevresinden saygı gören, ona ilk danışılan çoğu kez de karar verilmesi sürecinde son sözü söyleyen kişi olarak kabul görmüştür. Ancak geleneksel yapıyla oluşmuş geleneksel aile yapısı bazı ailelerde varlığını devam ettirse de özellikle sanayileşmenin, ekonomik gelişmenin, küreselleşmenin ve birçok diğer unsurların etkilerine bağlı olarak değişime uğramış ve gittikçe çekirdek aileye dönüşmüştür. Bu değişime paralel olarak kadının toplum içindeki konumunun değişmesi ve kadının iş hayatında daha belirgin bir şekilde görülmesi ile evdeki yaşlıya bakımı yerine getirecek kişi olan kadının görevini yerine getirememesi ortaya çıkmıştır. Hem yaşlının rahat bir hayat yaşaması hem de yaşlının statüsü olumsuz olarak etkilenmiş, bu konuda sosyal politikanın geliştirilmesi gereği ortaya çıkmıştır (Karacan, 2017, s. 640).

Türkiye'de Yaşlıların Durumu ve Yaşlanma Ulusal Eylem Planı Uygulama Programı gibi çalışmalar içerikleri itibariyle yaşılılar ile ilgili umut veren hedefler olmasına rağmen çoğu kez bu amaçlar uygulamaya konulamaması durumu söz konusudur. Bu tür plan ve stratejilerin başarılı sonuçlar vermesi için hem merkezi yönetim hem de yerel yönetim düzeyinde benimsenip içselleştirilmesi gerekir. Bu yüzden bu hedeflerde başarıya ulaşılması için en önemli nokta merkezi yönetim ve yerel yönetimler arasında işbirliği ve koordinasyonun sağlanmasıdır. Merkezi yönetimin ve onun taşra birimlerinin bu hedeflere ulaşması için göstermiş oldukları çaba kadar yerel yönetimlerin de bu konuda gerekli gayreti göstermesi ve bu konuda faaliyetlere yönelmesi gerekir. Çünkü yerel yönetimlerin yaşlılara yönelik olarak önemli sayllacak derecede görev ve sorumlulukları vardır. 5393 sayll Belediye Kanunu ve 5302 sayllı İl Özel İdaresi Kanunu'nda bu hizmetlerin sunumu konusunda bu birimlerin yaşlıların özel durumlarına uygun yöntemlerin geliştirileceği hükmü bulunmaktadır. Yaşlı bireylerin yerel hizmetlere erişim konusunda sıkıntı yaşamalarını ortadan kaldıracak olan birimler, halka en yakın olan yerel yönetim birimleridir. 5216 sayllı Büyükşehir Kanunu'nda hem büyükşehir belediyesine hem de büyükşehir ilçe belediyesine yaşlllara yönelik sosyal ve kültürel nitelikte hizmetlerin yürütmesi amaciyla görev ve sorumlulukları bulunmaktadır. Bu düzenleme ile büyükşehir olan yerlerde yaşlı insanların hizmetlere erişebilme konusuna ilişkin genel düzenlemelere ek olarak bir de sosyal ve kültürel hizmetlerle ilgili ek sorumluluklar verilmiştir. Yaşlılara yönelik sunulacak hizmetler sadece bakım, koruma ve rehabilitasyon amaçlı huzurevleri açmak ve yaşlıların gıda ihtiyaçlarını karşılamak, sağlık hizmetlerinin sunulması gibi temel hizmetlerle kısıtlı olmaması gerekir. Bu konuda bazı belediyeler ekonomik yeterlilikleri çerçevesinde yaşlıları, toplumsal uyumlarının sağlanması amacıyla çeşitli geziler, davetler düzenlemektedir. Ancak yerel yönetimlerin genel anlamda yaşlılara yönelik olarak sunduğu hizmetlerin çeşitlerinin ve kalitesinin artması sahip olunan ekonomik yeterlilik kapsamında gerçekleşecektir. $\mathrm{Bu}$ da sunulan yerel nitelikteki hizmetlerin Türkiye'nin her yerinde aynı kalitede ve aynı çeşitlilikte olmasına engel oluşturmaktadır (Çolak ve Özer, 2015, s. 118).

Yaşlı nüfusun hızla artmasından dolayı kamusal sosyal harcamalar da buna bağlı olarak artmaktadır. Bütçesi yetmeyen ülkeler bu harcamaları karşılamak için yeni arayış içerisine girmektedir. Buna en güzel örnek Almanya verilebilir. Bakım hizmetlerini ileriki zamanlarda aynı şekilde verebilmek için 1995 y1lından itibaren bakım giderlerinin büyük bir kısmını sosyal sigortalar sistemine yatırlan bakım primlerinden sağlamaktadır (Aydın, 2005, s. 16).

Demografik yaşlanma süreci çoğunlukla çalışan insanlar tarafindan olumsuz algılanır. Bu bakımdan yaşlıların toplumdaki konumu tartısmalıdır. Yaşlılıkla ilgili olumsuz imajlar (çaresizlik, ilgisizlik, hastalık) söz konusudur. Yaşlıların sorunlarının toplum tarafindan çözülmesi potansiyeli halâ sınırlı düzeydedir (Bucher, 2014, s. 32).

Yaşlıların emekli olmalarıyla birlikte gelirlerinde bir düşüş olmakta, bu durum yaşliların toplumsal olarak statülerinin düşmesine yol açmaktadır. Emekli olan yaşlı bireylerin yaşlılıkla beraber diğer birçok sorunlarının ortaya çıkmasına, gittikçe yalnız yaşamaya neden olmaktadır. Yalnız yaşamak çoğu toplumda 
yaşlılı̆ın en önemli sorunları olarak karşımıza çıkmaktadır. Yalnız yaşayan bireylerin psikolojilerinin bozulmasına neden olmaktadır. Bu yüzden yaşlıların yalnız kalmalarını önleyecek sosyal ortamların oluşturulması, oluşturulan projelerin sürekliliğinin olmasına dikkat edilmesi gerekir. Yaşı kişilerin üretkenliklerinin sağlanması için değișik uğraș alanları oluşturularak yaşlıların bu aktivitelerin içine girmeleri sağlanmalıdır. Onlara boş zamanlarını değerlendirecek bir meşguliyet sağlanarak yalnızlıktan kurtulmaları sağlanacaktır (Narin, 2019, s. 34).

Günümüzde insanlar daha uzun ve daha sağlıklı yaşamaktadır. Bu halk sağlığındaki başarıyı, tıbbi ilerlemeyi ve hastalıklar üzerindeki ekonomik gelişme sayesinde binlerce insanın yaşam beklentisini artırmaktadır. Ancak dünyada yaşlı nüfusun sürekli olarak büyümesi bazı zorlukları da beraberinde getirmektedir. Yaşlı nüfus, ekonomik büyümeyi, sosyal destek sistemlerini ve vatandaşına kaynak sağlamak zorunda kalacak otoriteleri etkilemektedir. Bu bakımdan ülkeler yeni demografik gerçeklik doğrultusunda mevcut politikaları buna göre ayarlamaları (örneğin emeklilik yaşlarında, tıbbi değişiklikler konusunda) gerekmektedir. Aksi durumda ülkeler için daha kolay sorunlar aşlamaz hâle gelebilir (Dobriansky, Suzman ve Hodes, 2007, s. 4-5). Yaşam beklentisinin artması ile yaşılıarın nüfus içindeki payını artırmaktadır. Özellikle sanayileşmiş ülkelerde yaşam beklentisinde çarpıcı bir artış söz konusudur (Bengtsson ve Scott, 2010, s. 10).

Özellikle aktif bir yaşamları bulunan bireyler bir süre sonra çeşitli sebeplerle çalısma hayatlarından ayrılmışlar ise kendi istekleri doğrultusunda kendi fiziksel koşulları, yaş ve diğer durumlar da göz önüne alınarak uygun işlere yönlendirilmelidir. Gerekirse yapmak istedikleri işle ilgili eğitim verilmelidir. Kişinin kendi evinde ya da başka bir işyerinde yapabileceği işlere yönelik esnek çalışma saatleri düzenlenerek çalışmaları sağlanabilir. Ayrıca bu tür bir uygulama kişinin pasif sigortalılık durumundan aktif sigortalı durumuna geçişini sağladığı için sosyal güvenlik kurumuna mali açısından olumlu bir etkisi de olacaktır. Ayrıca gerek kamu kurumları tarafindan kurulan gerekse de özel sektör tarafindan kurulan huzurevlerinin yapılanmalarında ve sunulan hizmetlerde tam bir birlik oluşmamıştır. Devlet tarafindan kurulan huzurevleri arasında bir standartlaşma sağlanmalı, hizmet kalitesi yükseltilerek eşit hale getirilmelidir. Özel sektör tarafindan kurulan huzurevleri de aynı şekilde sunulan hizmetler konusunda standartlaşma sağlanmalıdır. Hem devlet tarafindan hem de özel sektör tarafindan kurulan huzurevlerinin sürekli olarak denetimleri yapilmalıdır (Karacan, 2017, s. 641-642).

Toplumlar yaşlandıkça ülkelerde yaşlı popülasyon oranları da artış göstermektedir. Bu yüzden yaşlı hastalar ve aileleri özel tedavi ve fiziksel yetersizlik gibi birtakım sorunlarla baş başa kalmakta ve bu konularda alternatif yöntem arayışı içerisine girmektedirler (Bilge vd., 2014, s. 1).

Ülkemizde yaşlılara yönelik olarak sunulan hizmetlerin organizasyonuna, hizmet veren kişilerin nitelikli eleman sayısının arttırlmasına, yapılan değerlendirmeler kapsamında gerekli tedavi yöntemlerinin uygulanmasına, yaşlılara ve ailelerine yönelik eğitim hizmetlerinin gerçekleştirilmesine, aktif ve sağlıklı yaşam sürdürülmesine ilişkin danışmanlık hizmetlerinin sürdürülmesine, öncelik olarak kendi bakımlarını kendilerinin yapabilmelerine yardımc1 olmak, kronik rahatsızlığı olanlarının bakımlarının evde gerçekleştirilmesine imkân sağlanması gerekir (Dönümcü, 2006, s. 45).

\section{Sonuç}

Yaşlılık bütün insanların doğumdan başlayarak ölümüne kadar yaşadığı bir süreci anlatmaktadır. Dolayısıyla insanların bu süreçten kaçması imkânsızdır. Yaşlilık genel olarak yetersiz olma durumunu anlatmaktadır. İçinde bulunduğumuz çağda demografik değişimler dikkat çekmektedir. Birinci ve İkinci Dünya Savaşı'nın en önemli sonuçlarından biri de bu savaşlarda genç sayılabilecek insanların hayatlarını kaybetmesidir. Dolayısıyla yaşanan bu savaşlardan sonra genç nüfusun azalması sonucu ülkelerin nüfuslarının demografik yapıları önemli ölçüde değişime uğramıştır. Genç nüfusun azalmasına bağlı olarak yaşlı nüfusu artış göstermiştir. Özellikle son dönemlerde yaşılların nüfuslarının artmasının diğer önemli nedenlerinden biri de ortalama yaşam süresinin giderek artmasıdır. Son dönemlerde çalışma ve hayat koşullarının iyileştirilmesi, teknolojik gelişmelerde yaşanan baş döndürücü gelişmeler, sağık alanında yaşanan olumlu gelişmeler insanların daha uzun yaşamalarını sağlamaktadır.

Özellikle son dönemlerde geniş aile yapısının terk edilerek çekirdek tipi aile yapısına geçilmesi yaşlıları toplumda daha savunmasız hâle getirmektedir. Geleneksel aile tipi olan geniş aile yapısında yaşlıların aile içinde önemli bir yeri ve konumu bulunmaktaydı. Onların bilgi birikimlerinden, tecrübelerinden önemli ölçüde yararlanılmaktaydı. Ancak çekirdek aile yapısına geçilmekle birlikte, yaşlılara çekirdek aile içinde yer 
verilmemektedir. Yaşlılar aileye birer yük olarak görülmektedir. Bu değişimlerin yaşanmasının nedenleri arasında; kırsal alanlardan kentlere olan göçün artması, kadınların çalışma hayatlarına katılmaları gösterilebilir. Bu nedenlerden dolayı yaşlılar artık tek başlarına hayatlarını geçirmek zorunda kalmaktadırlar. Bu noktada sosyal devlet ilkesini benimseyen ülkelerin, ülkelerinde yaşayan yaşlılara yönelik sosyal politika uygulamaları hayata geçirme zorunluluğu ortaya çıkmaktadır.

Yaşının ilerlemesinden dolayı eski alışkanlıklarını yerine getiremeyen, ihtiyaçlarını kendi başına karşılamakta yetersiz kalan yaşılıara yönelik sosyal politikalar uygulama alanı bulmaktadır. Yaşılıarın özellikle çalışma hayatında ya da sosyal hayatında herhangi bir ayrımcıllğa maruz bırakılmamasını, sosyal hayata aktif bir şekilde katılımını sağlamak temel amaçlar arasındadır. Bu kapsamda ülkemizde Aile, Çalışma ve Sosyal Hizmet Bakanlığı hizmet vermektedir. Yaşlılara yönelik uygulanacak bütün sosyal hizmet uygulamalarının tek çatı altında toplanmasını amaç edinmiştir. Bakanlığa bağlı olarak Engelli ve Yaşlı Hizmetleri Genel Müdürlüğü yaşlılara hizmet vermek amacıyla özel olarak kurulmuştur.

Yaşlılara yönelik oluşturulan sosyal politikaların yürütücüsü kimi zaman yerel yönetim birimleri kimi zaman özel kuruluşlar kimi zaman da devlet olmaktadır. Bu noktada ülkemizde de aynı durum söz konusudur. Hizmetlerin götürülmesi aşamasında bir dağınıklık göze çarpmaktadır. Kimi zaman aynı kişi birden fazla sosyal hizmet çeşidinden yararlanmakta iken kimi zaman diğer ihtiyaç sahibi hiçbir hizmetten yararlanmadığı durumlar ortaya çıkmaktadır.

Tüm dünyada olduğu gibi ülkemizde de aile yapısı değişmeye başlamıştır. Modernliğin getirdiği değişimle beraber aile yapısı çocukların daha erken yaşta evden ayrılmalarına, çocukların çok küçük yaşlarda ailelerinden ayrılarak günün yarısını kreşlerde geçirmelerine, yaşlı insanların bakımlarının zor gelmesi nedeniyle huzurevlerinde yaşamalarına neden olmaktadır. Kimi zaman aileler, yaşlı insanların yaşamlarını devam ettirmek amacıyla verilen emekli maaşlarını ya da evde bakım ücretini almak amacıyla yaşlılara baktıkları görülmektedir. Dolayısıyla kimi zaman değişik zamanlarda habersiz bir şekilde denetim yapılarak yaşlıların bakımı konusuna daha hassasiyetle yaklaşılmalıdır. Aktarılan kaynakların ne şekilde kullanıldığı konusunda 1srarlı bir şekilde takip edilmelidir. Belki de bu sistem sayesinde yaşlılara bakan insanların her an bir denetimden geçeceği korkusuyla en azından yaşlılara daha insancıl yaklaşımları olabilecektir.

Ayrıca ülkemizde barınacak yeri olmayan, bakıma muhtaç kişilere yönelik hizmet veren diğer bir kuruluş huzurevleridir. Çoğu zaman yaşlılar evde ailesi tarafindan kötü muameleye maruz kalsa dahi huzurevlerinde kalmamak için kötü muameleye ses çıkarmamaktadır. Bu yüzden huzurevlerinin yaşam koşullarının bu kapsamda iyileştirilmesi ve insanların kalmak isteyecekleri, huzur bulacakları yerler olarak yapısının değiştirilmesi gerekir.

Aslında ülkemizde yaşanan çoğu sorunlarda olduğu gibi yaşlılara yönelik uygulanan sosyal politikaların daha anlamlı olması ve daha etkili çözümler getirmesi amacıyla belki de en önemli konu olan aile konusuna gereken önemin verilmesi gerekmektedir. Ülkemizde yaşlılara yönelik uygulanan sosyal politikalar gerçekten önemli sayılacak derecede ve niteliktedir. Ancak bu uygulanan politikaların amacına ulaşması için aile konusuna odaklanmak gerekir. Ülkemizde geleneksel Türk aile yapısı kaybolmaya başlamaktadır. Eskiden yaşlılara yönelik bu kadar sayıda sosyal politika uygulamada değildi. Çünkü eskiden yaşlılar bizim başımızın tacı idi. Evlerimizde, sofralarımızda yaşlılarımızın her zaman bir yeri bulunmakta idi. Onlar sofraya oturmadan kimse oturmazd. Ancak günümüzde modernleşmeyle birlikte yaşlılarımızı hor görür olduk. Bu yüzden ülkede yaşlılara yönelik olarak yaşanan sorunların en aza indirilmesi için aileye yönelik sosyal politikaların arttırılması gerekmektedir. Aileyi bir arada tutacak, aile bağlarının güçlendirilmesine yönelik politikalar uygulanabilir.

\section{Etik Beyan}

"Sosyal Politika Kapsammda Türkiye'de Yaşlanmaya Ilişkin Ulusal Düreydeki Düzenlemeler” başlıklı çalıșmanın yazım sürecinde bilimsel kurallara, etik ve alıntı kurallarına uyulmuş; toplanan veriler üzerinde herhangi bir tahrifat yapılmamış ve bu çalşma herhangi başka bir akademik yayın ortamına değerlendirme için gönderilmemiştir. $\mathrm{Bu}$ araştırma doküman incelemesine dayalı olarak yapıldığından etik kurul kararı zorunluluğu bulunmamaktadır.

\section{Kaynakça}

Aile ve Sosyal Politikalar Bakanlığı (2013). Türkiye'de yaşlıların durumu ve yaşlanma ulusal eylem planı uygulama programi.https://www.tatd.org.tr/uploads/tbl_calisma_grubu_belgeleri/5bdc0c422b9e3_tbl_calisma_grubu_b elgeleri2018113514.pdf. 
Aile, Çalışma ve Sosyal Hizmetler Bakanlığı. (2019). I. Yaşlılık şurası sonuç bildirgesi. Ankara.

Altan, Ö. Z. ve Yener, Ş. (2003). Yaşlilara yönelik sosyal politikalar. Kamu-İs; 7(2), 2-36.

Aydın, D. (2005). Avrupa'da yaşlı bakımı. Ankara: Sağlık ve Eğitim Yayınları.

Bengtsson, T. ve Kirk, S. (2010). The ageing population. İçinde T Bengtsson (Edt.). Population ageing - $A$ threat to the welfare state? The case of sweden (pp. 7-22). Berlin: Springer.

Bilge, U., Elçioğlu, Ö., Ünalacak, M. ve Ünlüoğlu, İ. (2014). Türkiye'de yaşlı evde bakım hizmetleri. Euras J Fam Med, $3(1), 1-8$.

Bucher, S. (2014). Selected indicators of population ageing in the world: Trends, impacts and consequences. Geographica Pannonica, 18(2), 26-33.

Cengiz, I. (2018). Türk sosyal güvenlik sistemi içerisinde yaşlilara yönelik sosyal yardım ve sosyal hizmetler. Sosyal Güvenlik Dergisi, 8(2), 23-40.

Çağlar, T. (2014). Yaşl11ık ve sosyal hizmet: yaşam destek merkezi örneği. Toplum ve Sosyal Hižmet, 25(2), 145-162.

Çayır, K. (2012). Yaşçlık/yaşa dayalı ayrımcılık. İçinde K. Çayır ve M. Ayan Ceyhan (Derleyenler). Ayrmmcıllk çok boyutlu yaklaşımlar (ss. 163-174). İstanbul: İstanbul Bilgi Üniversitesi Yayınları.

Çohaz, A. (2010). Türkiye'de yaşlı ve yaşlılara sunulan bakım hizmetleri. Akademik Geriatri,

Çolak, M. ve Özer, Y. E. (2015). Sosyal politika anlamında aktif yaşlanma politikalarının ulusal ve yerel düzeydeki analizi. Elektronik Sosyal Bilimler Dergisi, 14(55), 122-126.

Devlet Planlama Teşkilatı (2007). Türkiye'de yaşlllarn durumu ve yaşlanma ulusal eylem planı. Ankara: DPT Yayını.

Dobriansky, P. J., Suzman, R. M. ve Hodes, R. J. (2007). Why population aging matters: A global perspective. USA: National Institute on Aging National Institutes of Health.

Dönümcü, Ş. (2006). Yaşlı ve sosyal hizmetler. Türkiye Fiz̨ikesel Tip ve Rehabilitasyon Dergisi, 52(1), 42-46.

Engelli ve Yaşlı İstatistik Bülteni (2020). Engelli ve yaşh biæ̧metleri genel müdürlügü. www.ailevecalisma.gov.tr.

Hacettepe Üniversitesi Geriatrik Bilimler Araştırma ve uygulama Merkezi-GEBAM (2002). Yaşlanma 2002 uluslararası eylem plani.

İnalhan, G. (2020). İnsan, zaman, mekan, yerinde yaşlanma ve să̆lık, herkes için yaşanılabilir kent. Cogito, 98, 153164.

Kalkınma Bakanlığı (2019). Yaşlanma özel ihtisas komisyonu raporu. On Birinci Kalkınma Planı (2019-2023). Ankara.

Karacan, E. (2017). Sosyal politika kapsamında Türkiye'de yaşlı nüfus: sorunlar ve çözüm önerileri. Uluslararası Sosyal Arassttrmalar Dergisi, 10(49), 637-644.

Özürlü ve Yaşlı Hizmetleri Genel Müdürlügü (2013). Türkiye'de yaşlllarn durumu ve yaşlanma ulusal eylem plan uygulama programi. Ankara.

Narin, B. (2019). Türkiye'de yaşh politikalar ve yaşh ibmal ve istismarna yönelik uygulamalar (Yüksek Lisans Tezi). Sakarya Üniversitesi Sosyal Bilimler Enstitüsü, Sakarya.

Ökten, M. (2015). Yaşh bakıım ve bizmetleri yönetimi konusunda bir araștırma (Yüksek Lisans Tezi). İstanbul Arel Üniversitesi Sosyal Bilimler Enstitüsü, İstanbul.

Taşcı, F. (2010). Yaşlılara yönelik sosyal politikalar: İsveç, Almanya, İngiltere ve İtalya örnekleri. Calışma ve Toplum, 24, 175-202.

Tuncel, G. ve Uzun, H. (2019). Türkiye'de yaşlılara yönelik sosyal politikalar üzerine bir inceleme. Furat Üniversitesi İ̈BF Uluslararası İktisadi ve İdari Bilimler Dergisi, 3(2), 309-334.

Şeker, A. ve Kurt, G. (2018). Bir sosyal politika alanı olarak yaşlılık ve sosyal hizmet uygulamaları. Nüfus Bilim Dergisi, 40, 7-30.

Umutlu, S. ve Tekin-Epik, M. (2019). Türkiye'de yaşlı nüfus ve sosyal politika uygulamaları. Sosyal ve Beşerî Bilimler Dergisi, 11(1), 29-43.

Vepachedu, S. (2019). Aging population. www.researchgate.net/publication/331072071_AGING_POPULATION, $(17.05 .2020)$.

Yerli, G. (2017). Yaşl1lık dönemi özellikleri ve yaşlılara yönelik sosyal hizmetler. Uluslararası Sosyal Araştırmalar Dergisi, 10(52), 1278-1287.

http://www.tuik.gov.tr, (17.05.2020).

\section{EXTENDED ABSTRACT}

The concept of aging one of the inevitable life stages and must necessarily be experienced by the individual like other life stages. The beginning and end stages of the aging aren't clearly known. There are many biological, sociological and chronological definitions for aging. The World Health Organization has defined aging chronologically. According to the biological, physical, social, economic and cultural characteristics of the individual, some individuals spend their aging more comfortably, while others experience more troubles. It varies according to the level of life quality of elderly individuals. The decrease in birth rates, developments in the field of medicine and the change in technology, the average life expectancy is increasing gradually compared to previous times. It is seen that the social, economic and cultural problems experienced by the elderly gradually increase with the increase in life expectancy. The necessity to implement social policies for the elderly has emerged with increasing needs by diversifying, 
difficulty in meeting the needs of people settling in cities with the increase of migration from rural to urban, positive developments in the health sector, change in social life, and transition from traditional family type to nuclear family. While caring for the elderly is among the basic responsibilities of the family in the traditional family structure, today, with the spread of the nuclear family, meeting the care and needs of the elderly is an important problem area. In addition, with aging, individuals retire; they may experience economic difficulties as they withdraw from working life actively, and may face some biological problems. In the traditional family type, the elderly have a reputation and dignity in homes. However, in the modern society where the nuclear family is dominant, the elderly are considered a problem for families. The elderly population is increasing in Turkey has increased in the world. Despite the practices for the elderly in the world, the emphasis has been placed on our country in recent years. Integrative policies towards elderly people should be implemented to reduce their problems. In developed countries, a number of policies have been put into practice to relieve elderly people from addiction and to reintroduce them into working life in order to ensure their active participation in life. Until the industrial revolution, an important practice in social policy did not stand out. With the emergence of industrialization, the working class emerged, worked under much more difficult conditions, women and children had to work under bad working conditions. In this context, social policy practices have come to the fore for the protection and development of workers' rights, and to solve social conflicts and problems. Since aging covers an important aspect of human life stages, it is necessary to produce long-term policies regarding aging. This is a must for a successful aging process. Particularly, countries that adopt the social state principle have implemented different policies for elderly people, who are considered as disadvantaged groups, in order to provide them with a minimum life style within the social security system and to meet their socio-economic and cultural needs. Social policies for the elderly, who are among the disadvantaged groups in our country, are carried out by the Ministry of Family, Labor and Social Services. A unit called the General Directorate of Disabled and Elderly Services provides services under the Ministry. Nursing homes and care centers providing institutional care for the elderly provide services. Nursing homes meet the basic needs of the elderly such as nutrition, accommodation, eating and drinking. In addition to the compulsory needs, activities and programs are also organized for the active use of social and cultural free time. In Turkey must have completed at least 60 years old to stay in the nursing home, in a position to meet the needs alone, there is someone else must be at a level that would require the care and supervision. Nursing homes can be established by both public and private institutions in our country. In addition to nursing home services, home care services are also provided. In home care services, it is to provide home care of the elderly without leaving their homes and family lives. Within the scope of these services, the medical and individual needs of the elderly and their family members providing care are met. Home care services are provided by the family members of the elderly as well as by healthcare professionals. While elderly people are cared for separately from their families in nursing homes; In nursing homes, elderly people are happier because they are cared for with their families without leaving their environment, happy elderly people are psychologically stronger, making it easier to care and recover. At the same time, it enables family members who spend all their time looking after the elderly to have a better quality time, they are prevented from leaving working life. Elderly solidarity centers are another of the services provided for the elderly. Elderly solidarity centers, elderly solidarity centers established under private or public institutions to meet the physiological, social and psychological needs of the elderly living alone or living with their families. This type of service is provided during daylight hours. In these solidarity centers, simple social activities such as various activities, handcrafts and handcrafts are organized for the elderly who want to spend their free time more actively. In order to ensure the active participation of the elderly in social life, it is ensured that the elderly come together and chat with each other, listening to each other's troubles, the elderly who have a friend environment again feel happier. In this context, the study of social policy implemented in Turkey were examined. Turkey as well as in several countries around the world have also been evaluated and implemented policies for the elderly. The concept of aging was emphasized in the research, according to the latest data is illustrated by statistical data on the elderly population in Turkey. Active aging index, which has been developed to ensure their individuals age actively, has been mentioned. Active aging index is more important in terms of ensuring active aging of individuals as well as allows comparison of the potential of the elderly in other countries. In addition, the legal regulations applied for the elderly in our country were also evaluated. Institutional social policy is applied in our country in order to eliminate the problems of the elderly. It is seen that such regulations have been emphasized recently. Perhaps this is because, in the past, the issue of elderly care was not a problem for families and countries. However, in today's changing and developing world, the social structure is changing, terms and conditions unfortunately do not go as we want. Therefore, the elderly population is increasing in our country with the 
improvements in health conditions and the decrease in mortality rates. Maybe it will increase more in the future. It is necessary to ensure active participation of elderly people in social and economic life and to implement measures and policies to save them from being a burden for the country and their families. Changing conditions should be adapted by protected the possessed properties. Otherwise, it should' nt be understood as completely changing. Because every country, every society has its own characteristics. Change should be made while protected these features. Understanding that family structure forms the basis of society, measures must be taken to protect the family. 